\title{
Criminal Organizations and Illicit Trafficking in Guatemala's Border Communities
}

Ralph Espach, Javier Meléndez Quiñonez Daniel Haering, and Miguel Castillo Girón

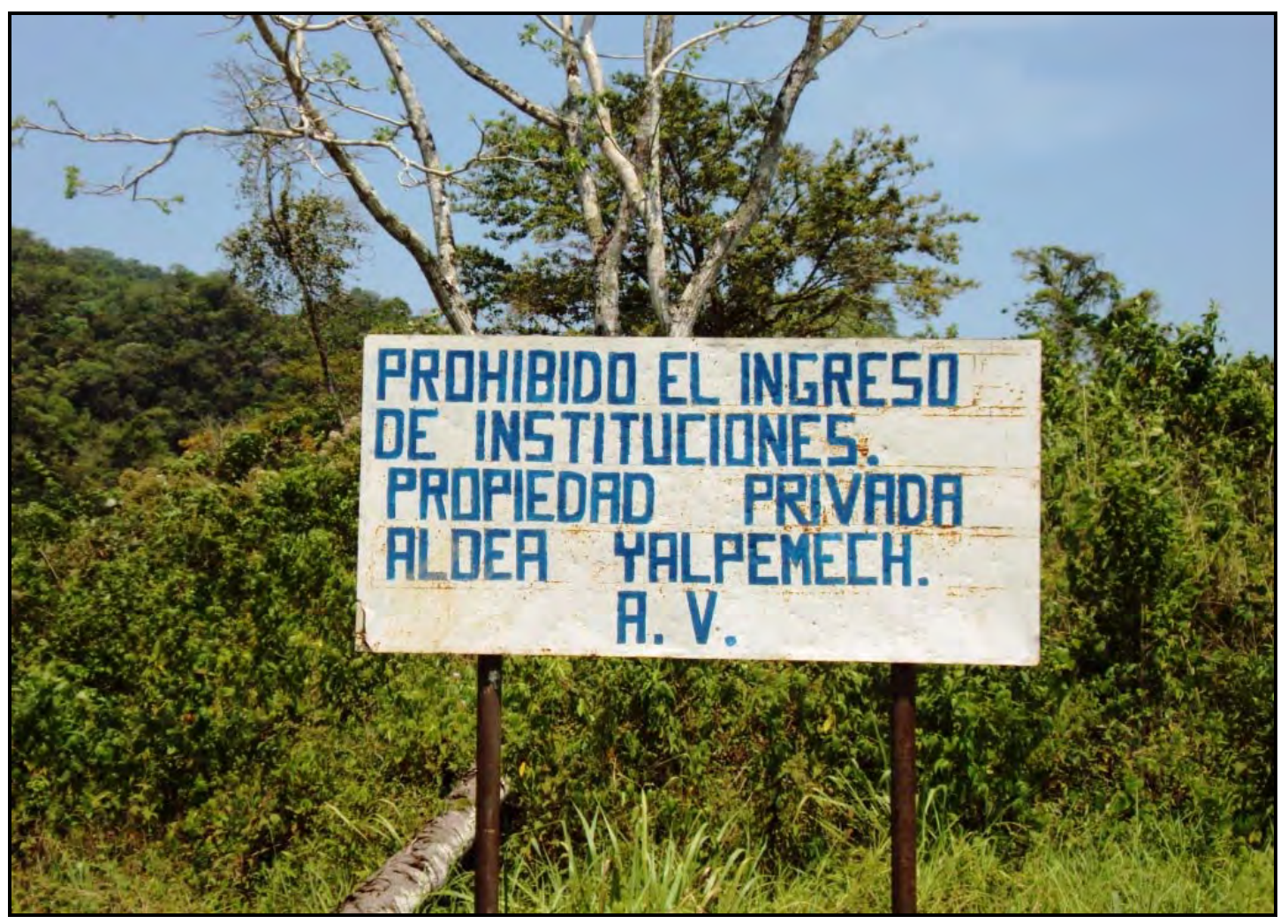




\section{Report Documentation Page}

Form Approved OMB No. 0704-0188

Public reporting burden for the collection of information is estimated to average 1 hour per response, including the time for reviewing instructions, searching existing data sources, gathering and maintaining the data needed, and completing and reviewing the collection of information. Send comments regarding this burden estimate or any other aspect of this collection of information,

including suggestions for reducing this burden, to Washington Headquarters Services, Directorate for Information Operations and Reports, 1215 Jefferson Davis Highway, Suite 1204, Arlington

VA 22202-4302. Respondents should be aware that notwithstanding any other provision of law, no person shall be subject to a penalty for failing to comply with a collection of information if it

does not display a currently valid OMB control number.

\begin{tabular}{|c|c|}
\hline $\begin{array}{l}\text { 1. REPORT DATE } \\
\text { DEC } \mathbf{2 0 1 1}\end{array}$ & $\begin{array}{l}\text { 3. DATES COVERED } \\
\mathbf{0 0 - 0 0 - 2 0 1 1} \text { to 00-00-2011 }\end{array}$ \\
\hline \multirow{3}{*}{$\begin{array}{l}\text { Criminal Organizations and Illicit Trafficking in Guatemala's Border } \\
\text { Communities }\end{array}$} & 5a. CONTRACT NUMBER \\
\hline & 5b. GRANT NUMBER \\
\hline & 5c. PROGRAM ELEMENT NUMBER \\
\hline \multirow[t]{3}{*}{ 6. AUTHOR(S) } & 5d. PROJECT NUMBER \\
\hline & 5e. TASK NUMBER \\
\hline & 5f. WORK UNIT NUMBER \\
\hline $\begin{array}{l}\text { 7. PERFORMING ORGANIZATION NAME(S) AND ADDRESS(ES) } \\
\text { CNA, } \mathbf{4 8 2 5} \text { Mark Center Drive,Alexandria,VA,22311 }\end{array}$ & $\begin{array}{l}\text { 8. PERFORMING ORGANIZATION } \\
\text { REPORT NUMBER }\end{array}$ \\
\hline \multirow[t]{2}{*}{ 9. SPONSORING/MONITORING AGENCY NAME(S) AND ADDRESS(ES) } & 10. SPONSOR/MONITOR'S ACRONYM(S) \\
\hline & $\begin{array}{l}\text { 11. SPONSOR/MONITOR'S REPORT } \\
\text { NUMBER(S) }\end{array}$ \\
\hline
\end{tabular}

12. DISTRIBUTION/AVAILABILITY STATEMENT

Approved for public release; distribution unlimited

13. SUPPLEMENTARY NOTES

14. ABSTRACT

15. SUBJECT TERMS

16. SECURITY CLASSIFICATION OF:

\begin{tabular}{c|c|c|}
$\begin{array}{c}\text { a. REPORT } \\
\text { unclassified }\end{array}$ & $\begin{array}{c}\text { b. ABSTRACT } \\
\text { unclassified }\end{array}$ & $\begin{array}{c}\text { c. THIS PAGE } \\
\text { unclassified }\end{array}$
\end{tabular}

17. LIMITATION OF ABSTRACT

Same as Report (SAR)

\begin{tabular}{|l|l|}
$\begin{array}{c}\text { 18. NUMBER } \\
\text { OF PAGES } \\
\mathbf{9 6}\end{array}$ & 19a. NAME OF \\
& \\
&
\end{tabular}


Approved for distribution:

December 2011

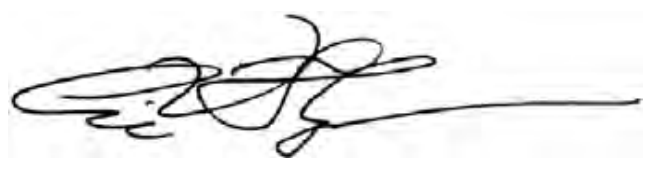

Dr. Eric V. Thompson

Acting Director, Strategic Studies

This document represents the best opinion of CNA at the time of issue.

It does not necessarily represent the opinion of the Department of the Navy.

Cleared for Public Release. Distribution unlimited. Specific authority: N00014-11-D-0323.

Copies of this document can be obtained through the Defense Technical Information Center at www.dtic.mil Or contact CNA Document Control and Distribution Section at 703-824-2123.

\section{Copyright $\odot 2011$ CNA}

This work was created in the performance of Federal Government Contract Number N00014-11-D-0323. Any copyright in this work is subject to the Government's Unlimited Rights license as defined in DFARS 252.227-7013 and/or DFARS 252.227-7014. 


\section{Acknowledgments}

Many friends and colleagues contributed to the research and writing of this report. Foremost the authors would like to thank the excellent Guatemalan research and analysis team at the Ibn Khaldún International Research Centre at the Francisco Marroquín University: Eduardo Fernández, Rodrigo Fernández, Javier Calderón, Marizza Herrera, Santiago Fernández, and Jorge Dardón. Without their field research and data collection across the country, this study would never exist. In addition, we owe a great deal of gratitude to Pedro Trujillo, the Director of the Institute of Political Studies and International Relations at the Francisco Marroquín University, and his team especially for organizing two workshops at which we had the opportunity to share our research with Guatemalan and international officials and experts who provided important additional perspective on the complexity of Guatemala's security situation. Similarly, we wish to thank Cynthia Arnson and Eric Olson and the rest of the staff at the Latin American Program of the Woodrow Wilson International Center for Scholars, in Washington, D.C., for co-hosting with us a conference in November 2011 which allowed us to learn from experts and practitioners from across the United States.

Several readers have offered comments on our research and analysis, and to all of them we are grateful. However, we need to thank especially Julie Lopez, who reports superbly on Guatemalan organized crime and security issues for PlazaPublica.com, and Werner Ovalle, the director of Border Security Programs at the Democratic Security Office of the Central American Integration System (SICA), for their thorough and thoughtful comments. Christopher Ashe, the U.S. Department of State Action Officer for the Central American Regional Security Initiative program, also provided helpful guidance at the beginning of our project, and illuminating commentary at the event at the Woodrow Wilson International Center. The colleagues and friends who contributed important information and helped us to understand better the complicated relations between Guatemalan citizens, their government, and criminal organizations, are too numerous to thank individually, but we feel we need to express our special appreciation to Tani Adams and Fernando Carrillo. And finally, the report would not be legible if not for the talent and hard work of our translators Alixe Huete, Silvia Amador, and Iciar Gómez, and our editor at CNA's Center for Strategic Studies, Sarah Vogler. 



\section{Contents}

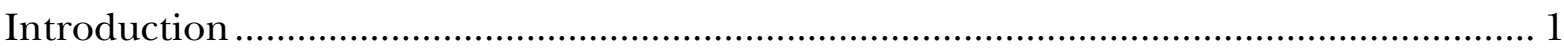

Criminal networks and activities in three border communities.....................................

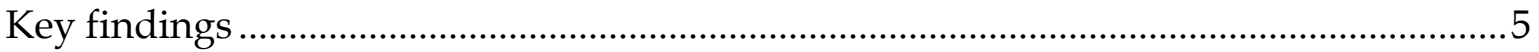

Security policy in the border region ....................................................................

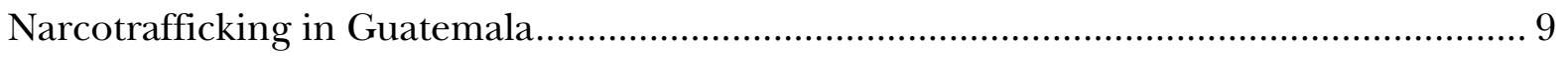

The peace process current conditions ....................................................................... 13

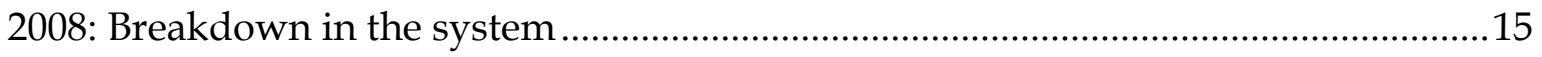

The Zetas as a new style of criminal organization ..................................................... 18

Borders in Central America: A perennial concern .................................................. 21

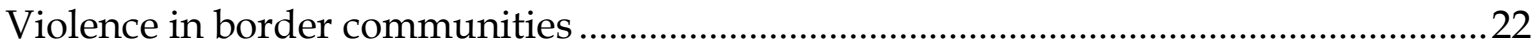

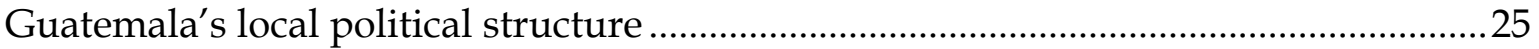

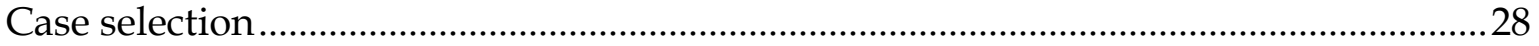

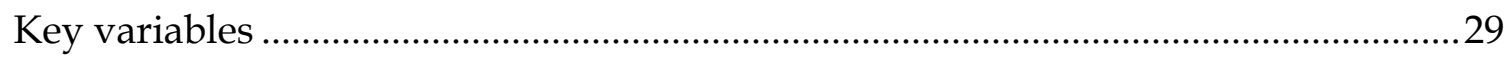

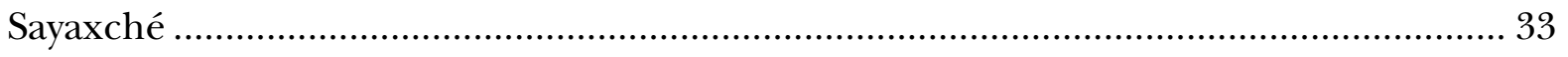

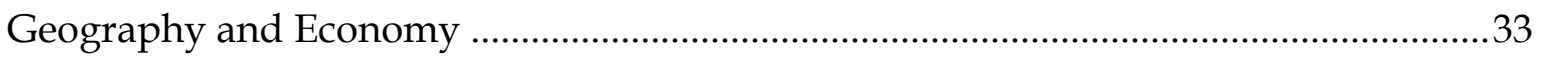

Migration, land ownership and a weak economy based on a system of extraction......34

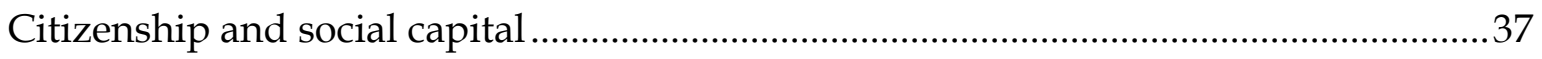

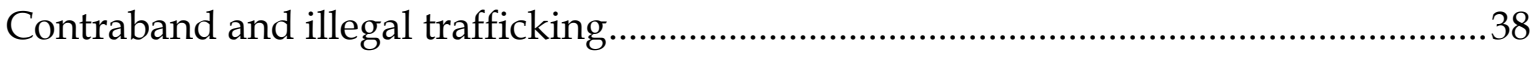

Economic and social impacts of organized crime.................................................... 40

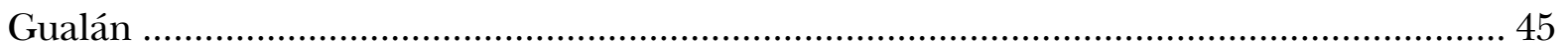




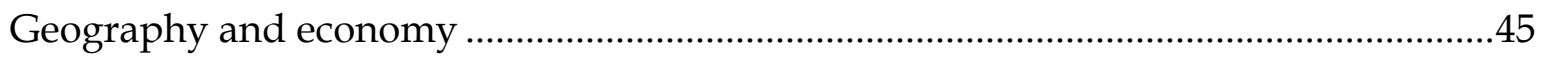

Politics and social capital in the community …………………………………………....47

The community and contraband: "Golden tomatoes"? .......................................................49

Los señores and security in Gualán ................................................................................52

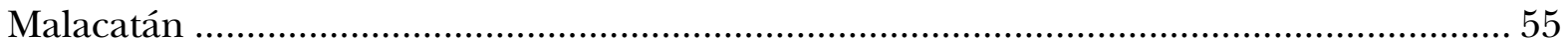

Geography and economy …………………………………………………………….....5

Local politics and community social capital..................................................................56

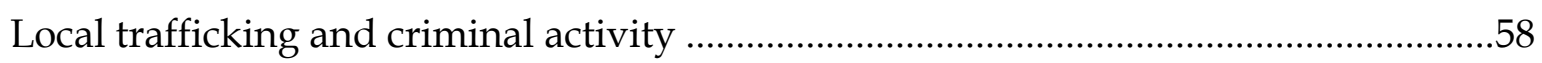

Drug trafficking in the community …………………………………………………....60

The local community's relationship with and reaction to organized crime ...................60

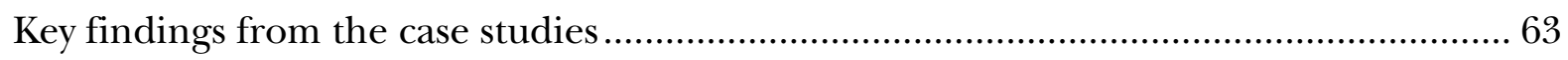

Social capital as a community resource.........................................................................64

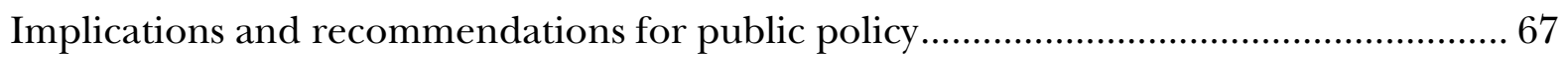

Recent regional initiatives in border security …………………………………………...68

Security reform and policies pertaining to border communities.......................................70

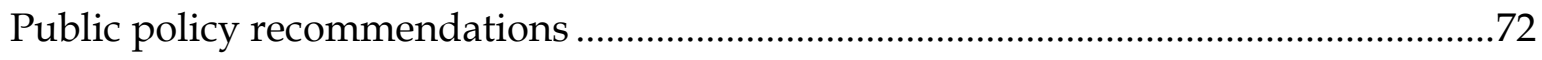

Measures for promoting social capital ....................................................................

Security zones and other measures to improve inter-agency security operations.....77

Police and institutional reform.......................................................................................

Measures to implement joint inter-agency action..............................................................79

Improving citizenship and social capital by increasing the resources and authorities of local governments .....................................................8

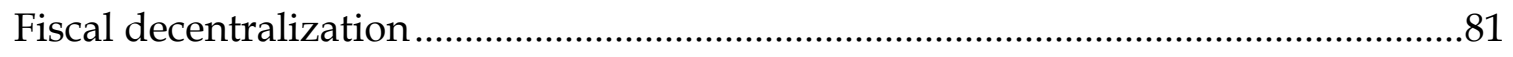

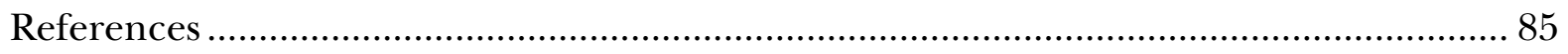




\section{Introduction}

Guatemala faces a growing, potentially existential threat. Territories and routes which once experienced moderate trafficking of goods, humans, and drugs have become superhighways for the transfer of high value products, chemical products, weapons, and cash required by the illicit drug industry. Due to Guatemala's border with Mexico and a permissive environment for contraband and crime, the country has become a funnel for 90 percent of the cocaine sent from South America to the United States-the largest drug market in the world. ${ }^{1}$

Contraband routes in Guatemala traditionally controlled by local groups are coming ever more under the control of the Mexican cartels. Around half of the nation's territory is believed to be under the control of criminal organizations. ${ }^{2}$ Local criminal organizations have long penetrated the Guatemalan police, army, courts and government, and Guatemala's gangs are extremely violent. However, the Mexican cartels with their financial resources, military grade weapons, and reputation for indiscriminate killing and brutality have elevated these threats. Today Guatemala and its neighbors Belize, Honduras, and El Salvador, have homicide rates among the highest in the world. Guatemala's murder rate is as high as those during the worst years of the civil wars in the 1980 's. Impunity for traffickers and murderers is the rule, not the exception.

Drug trafficking networks operate most intensely in communities along or near smuggling routes, many of which are located in border regions. Guatemala has more than 800 miles of borders which cross forests and mountain ranges and are seldom monitored or even marked. The communities close to the borders tend to be rural and engaged in subsistence farming often with little or no government presence in the form of clinics, schools, or police. Without the presence of state institutions, these communities are left vulnerable to exploitation at the hands of criminal groups which use a variety of tactics, including not only threats and violence but also the distribution of money, public services, and other benefits to obtain compliance, acceptance, and even the support of local residents.

\footnotetext{
${ }^{1}$ United Nations Office on Drugs and Crime. World Drug Report. 2010

${ }^{2}$ International Crisis Group, “Guatemala: Squeezed Between Crime and Impunity.” Latin America Report $\mathrm{N}^{\circ} 33$.
} 
Various independent and governmental reports have explained the gravity of the violence and organized crime in Guatemala, and the danger these factors pose to regional stability. ${ }^{3}$ These reports focus on the failures of national security policies, attempts to reform the national police and judicial systems, and international counter-narcotics efforts. Local dynamics which underpin this national crisis, such as the relationships between criminal networks and local authorities and institutions, go overlooked.

This report tackles this gap by examining the effects of illicit trafficking and criminal organizations within the three border municipalities of Guatemala: Sayaxché in the department of Petén, Gualán in Zacapa, and Malacatán in San Marcos. These municipalities sit on important smuggling routes and are well-known by Guatemalan police, intelligence agencies and local populations to be regional centers for organized crime. They differ in terms of their economies, demographics, political institutions, and the local and foreign criminal groups who control the trafficking.

In this report, we examine the local economic, political and social variables of these communities and how these factors shape the relationships between criminal organizations and local communities. The data is based on interviews and information collected during weeks of field investigation between April and July 2011. A comparison of these how these three economically and politically diverse communities have coped with local drug trafficking and criminal groups provides a broader understanding of the relational dynamics that determine the impacts of trafficking on nearby communities. We find the concept of "social capital," defined as a local community's capacity for self organization in seeking collective benefits, to be useful in describing these dynamics.

Our fieldwork and analysis lead us to conclude that effective border control and law enforcement in Guatemala is more about changing the habits and attitudes of local residents and communities, than it is about improving technology, infrastructure, or state presence per se. Based on these conclusions, we offer recommendations for policies designed to contribute to Guatemalan and international efforts to improve security, state presence, and the rule of law in these and other border communities.

\footnotetext{
${ }^{3}$ Ibid., also Hal Brands (May 2010) Crime, Violence, and the Crisis In Guatemala: A case study in the erosion of a state. U.S. Army War College Strategic Studies Institute.
} 


\section{Criminal networks and activities in three border communities}

Each case study represents a particular geographic and economic region of Guatemala, and each also sits on a principal trafficking route. The presence of the federal government in the three municipalities is limited, at best. Sayaxché is located on a river that is an important crossing point into Mexico and is relatively undeveloped and rural, with a transitory population. Livestock and large plantations for palm oil account for most of the region's economic activity. Gualán is located close to the border with Honduras in a rural and agricultural zone and its communities employ a traditional political structure in which just a few families, usually local landowners, provide public benefits and leadership in an informal manner. Malacatán is a relatively industrialized and diversified community along the country's principle route for contraband heading to Mexico.

Map 1: Geographical Location of the Three Case Studies

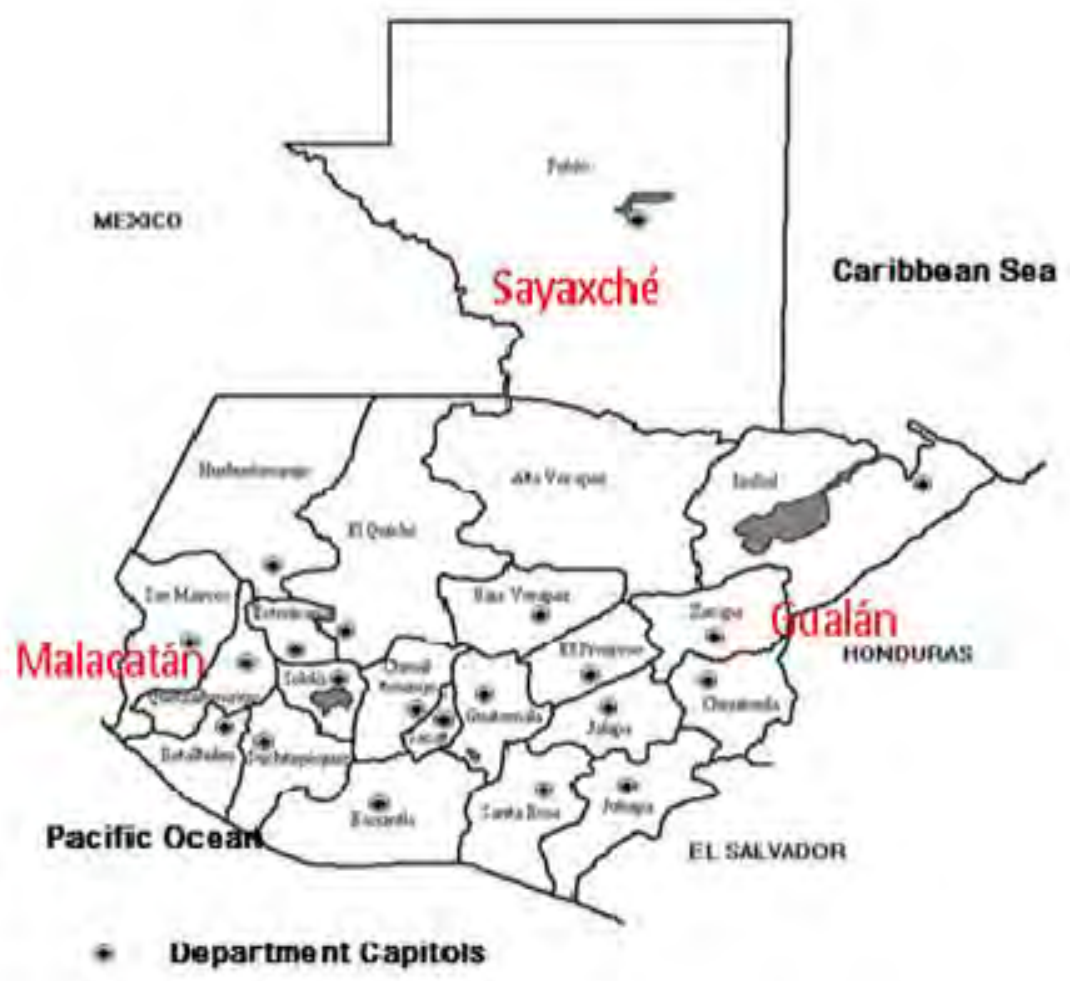

The communities included in this study differ significantly across a spectrum of political, economic, and social characteristics. These differences lead to variations in the political systems and institutions, their relationships with the national government and security forces and the interactions between the criminal organizations and the community. 


\section{Sayaxché}

Sayaxché is a relatively rural and primitive community undergoing rapid demographic change, with poor social capital. There are few churches, clubs, or non-governmental organizations to provide opportunities for social collective action, and the local government is widely disliked and perceived as corrupt. Mexican drug trafficking groups, especially the Zetas, are increasingly active in local trafficking and at times, are in cooperation with the Guatemalan Lorenzana group. Their presence is superimposed upon the traditional activities of the local population. The weaknesses of local institutions allows these groups to function in the region without having to accommodate themselves to or co-opt local actors or organizations, and they function relatively freely without hindrance from or interaction with the local community. Nevertheless, this criminal activity has had notable positive effects: economic growth, manifested primarily in the zones closest to the border with Mexico. Evidence for this can be seen in the fact that a small but growing middle class is sending its children to private schools at unprecedented rates. The Lorenzanas and their partners also provide a certain degree of security against common delinquency. In spite of these positive effects, the community in general regards the presence of these groups, and the increase in local residents' willingness to provide them services, with profound concern.

\section{Gualán}

The case of Gualán, located near the border with Honduras in a region of Guatemala known for its violent, frontier style of life, illustrates both the benefits and the costs of the rise in drug trafficking. Gualán is growing economically, especially in the production of tomatoes for export, but it is evident that much of the money is tied to drug trafficking. In spite of the existence of local institutions, the community's social capital seems limited. According to residents, the mayor's office is less a provider of services or leadership than a defender of local interests against a predatory federal government. Gualán has seen exceptional violence for decades, but even so, security has been worsening due to drug trafficking, even as Gualán's middle class expands. A network of local landowners and business entrepreneurs known as los señores, with ties to trafficking and criminal groups, has traditionally provided security against delinquents and common criminal activity, in place of the police. For many in the community, los señores continue to represent the best local defense against a possible take-over by Mexican cartels, and worst of all, by the Zetas.

\section{Malacatán}

Malacatán is a relatively large and prosperous community located along an important road near Guatemala's border with Mexico. For decades, the Malacatecos have prospered from the cultivation of coffee and various agricultural products in addition to the services 
typical of border cities, where commerce and contraband are ubiquitous. Malacatán enjoys a relatively high level of social capital, reflected in numerous organized interest groups, local churches, and associations many of which are industry-related. The mayor's office also has a strong presence and is recognized within the community for its capacity to conduct successful negotiations among diverse interest groups in the region, including the drug traffickers. The network headed by Juan "Chamalé" Ortiz (until his capture in May 2011) typified a criminal organization with deep roots in the local society and economy. Chamalé was considered in part a dangerous rogue, but to many he was seen as a benefactor of the local churches and families, and a "local farm boy made good". His arrest and possible extradition to the United States has created uncertainty and a measure of fear throughout the community.

\section{Key findings}

In spite of their many differences, these three cases are similar in important ways. Taken together, they reveal a portrait of border communities that is quite different from the usual assumptions that they are economically precarious, violent, anarchical, and "ungoverned". The following are some of the key themes that resonate across these cases:

- Border communities are prospering, in part due to the recent increase in drug trafficking. Contrary to the idea that delinquency and violence drive away investment and undermine local economies, these cases show exceptional levels of economic growth and dynamism in spite of growing levels of violence. In fact, border communities tend to be relatively resistant to economic and social pressures and to crises, largely due to consistent opportunities for border arbitrage. Recently, the increase in drug trafficking in and around Sayaxché, Gualán, Malacatán and has boosted local investment, employment, income, population growth, and even school matriculation. The degree to which this increase in economic activity may be tied to money laundering of contraband profits is not clear, although local citizens openly assume that this is the case. Growing economic diversity in these communities-investments in new types of crops and services-and increasing rates of school attendance suggest the growth of a small middle class, even within relatively isolated communities. The acknowledgement of the positive consequences of drug trafficking for the local economy, and in particular for family incomes and 
opportunities, complicates the challenge the government faces in its efforts to reduce illegal trafficking and other criminal activity in these areas. ${ }^{4}$

- Greater levels of social capital improve community resistance and reduce the violence and instability caused by local trafficking groups. Illegal trafficking abounds along Guatemala's borders. However, trafficking groups do not function in the same manner in each region or community. These cases demonstrate a variety of levels and types of social capital. In Gualán, social activities are moderated by long-standing networks of powerful local families and individuals (los señores), which provide security and other benefits to local community members in exchange for non-interference in their illicit activities. In Malacatán, a large and diverse business community and a relatively large population with virtually full employment are organized in part through a competent municipal government. This dynamic limits the reach and impact of the drug trafficking groups which, in spite of enjoying strong local ties, must function as just another interest group among many when it comes to interacting with local institutions including the government. Sayaxché, of our cases the poorest community and with the most transitory population, is primarily comprised of an indigenous population which tends not to create formal organizational structures. Sayaxché demonstrates the least amount of social capital. The drug traffickers in the region operate openly, with fewer ties to the community and little need for local acceptance.

- Municipal independence and leadership is important for coordination among community groups and their interests. In all three cases, the local communities describe the national government as, at best, absent and negligent and at worst, as corrupt and predatory. During our investigation of the three communities, we did not encounter the sentiment that if the national government were more present or active, it might effectively resolve the local security problems. Instead, the focus of public interest in government is on the strengths and especially the deficiencies of the municipal government. This is due in part to the constitutional provision stipulating that municipal governments provide the greater portion of day to day services required by the population, which naturally leads to the municipal governments being perceived as centers of political relevance. In Malacatán, the municipal government is considered to be relatively competent and responsible, effectively maintaining low levels of violence and crime in spite of the prevalence of drugs and human trafficking. This is accomplished in part

\footnotetext{
${ }^{4}$ For a Guatemalan perspective of this phenomenon, see the editorial opinion section and comments of Gutiérrez E. (August 24, 2011). "El 'boom' del interior". El Periódico. http://www.elperiodico.com.gt/es/20110113/opinion/188439
} 
through mediation between the interests of local criminal organizations and the needs of the community. In Gualán, the federal state is seen as part of the problem, due to corruption and the diversion of local resources, rather than part of the solution. The local government and police seek to avoid conflicts with los señores who control the flow of drugs, humans, and other contraband, and are involved in the large-scale laundering of money into local industries and agriculture. In Sayaxché, the municipal government is unpopular and perceived as corrupt, and appears to play a minimal role in relations among citizens, local businesses, and criminal organizations. Citizens in Sayaxché feel highly vulnerable to the demands and whims of drug traffickers.

\section{Security policy in the border region}

Due to public concerns over the increase in violence and organized crime, and in part due to international pressure, the Guatemalan government has initiated a series of measures meant to reform the political and judicial systems and promote education, job training, and youth services. The objective is to combat delinquency and violence by targeting their social and economic roots. These are important and promising policies. Nevertheless, they are costly and difficult to maintain. Such policies require several years for results to be seen, and they tend to be more readily applied in urban centers rather than rural areas. The policies and reforms that we offer for consideration are designed for short- to medium-term application, and are tailored to respond to the unique situations in the border regions. We see them as potentially complementary to and supportive of the government's long-term efforts, but providing more immediate results in terms of security.

Our comparison of case studies leads us to emphasize that policies should not be "onesize-fits-all," designed in detail at the national level, but flexible to fit local conditions and resources. Each community faces its own specific security issues and has a unique set of resources-as well as deficiencies-that can be used to address their security needs. From this perspective, our recommendations tend to promote policies, reforms and programs that include local communities in their design and execution, improve the autonomy and capacities of the municipal governments, and foster alignment and coordination between national and local efforts.

We discuss the following recommended measures in more detail in the final chapter of this report:

- Improve social capital on the community level. These include fiscal and business incentives to improve local diversity, and events and programs that 
promote cooperation among the various associations and local groups and boost support for public service activities.

- Encourage the federal government to promote the use of resources to compensate for the creation of social capital at the municipal level.

- Create inter-institutional and public-private working groups to supervise the security policies and practices in designated security zones. By operating across departmental borders and supervising security operations within regions where particular routes are found or where certain groups are active, one can better understand local problems and threats, and thus coordinate interinstitutional efforts to confront them.

- Redefine the roles and authorities of the national police and the army, with a focus on strengthening the national police as an institution.

- Promote public dialogue on the national and local levels regarding security, citizenship, and the rule of law. Also, encourage citizens to envision public institutions and security forces as instruments for their own security and protection of their rights.

- In the long-term, Guatemalans should consider a form of fiscal federalism in order for municipal governments to collect and spend a greater proportion of national taxes, under new rules, with tools to guarantee transparency and full accountability. 


\section{Narcotrafficking in Guatemala}

The history of drug trafficking practices, routes, and organizations in the Americas is well documented. $^{5}$ In this section we focus on the recent history of the trafficking of drugs through Guatemala and in particular on the local institutions and figures that have played key roles in that trafficking.

The widespread smuggling of food products, gasoline, and other contraband has been common across Guatemala's borders for several decades, and presumably long before. In isolated, rural communities particularly along Guatemala's 600-mile border with Mexico, residents cross unmarked borders on a weekly or even daily basis to buy or sell products, to work, to visit family, or to receive public services. ${ }^{6}$ As in most of Central America and indeed the world, border communities are in part defined by commonness of border arbitrage and its effects on local life.

\section{The 1980s: the emergence of cocaine trafficking with military and government involvement}

Highland Guatemalans have cultivated poppies and sold heroin paste to Mexicans for decades. However, larger scale drug trafficking and the trafficking of cocaine became significant in the country only in the 1980s. In those years, a combination of circumstances and policies combined to create an enduring national patchwork of trafficking routes and local criminal groups, many with ties to national and local political

\footnotetext{
${ }^{5}$ See, for example, Paul Gootenberg, Andean Cocaine: the Making of a Global Drug; Peter Chalk, The Latin American Drug Trade: Scope, Dimensions, Impact, and Response; and for a more provocative account critical of U.S. involvement, see Peter Dale Scott and Johnathan Marshall, Cocaine Politics: Drugs, Armies, and the CIA in Central America.

${ }^{6}$ As part of a CNA research project in 2010, CNA analysts visited and conducted interviews with community members in several small communities or aldeas, and one town, Sibinal, in the mountains of the San Marcos department along the Mexican border.
} 
parties and legitimate economic and social institutions. ${ }^{7}$ In some cases, including two of the case study communities we will discuss in the next section, these groups and their inter-relationships with legitimate businesses, political parties and officials have endured to the present.

During the 1980s, particularly after 1983, the army's counter-insurgency campaign succeeded in shrinking guerrilla activity and driving it into remote areas. As a result the level of violence declined. Areas of Guatemala that had been the focus of bloody and turbulent anti-insurgency campaigns, waged by thousands of troops and paramilitary Civilian Patrols (PACs), quieted. At around the same time, Colombian traffickers faced growing efforts by the U.S. Drug Enforcement Agency and Defense Department to interdict illegal drug shipments from Colombia, across the Caribbean, to Florida or to the Gulf shore. These cartels sought new routes and found in Guatemala a network of existing trafficking zones and routes, controlled jointly by local community leaders and by military officials who could guarantee easy transit even at formal border crossings.

By 1980, the civil war had lasted 20 years and the country had been under military rule for 26 years since the U.S.-sponsored coup against President Arbenz in 1954. The military was present in virtually all of the country, and due to the prolonged violence which included the complete elimination of several hundred villages, the presence of other state agencies, including the police, had dwindled to virtually nothing. By dint of its perch in the executive branch and the control imposed by army commanders from bases and mobilized units across the country, the military controlled or oversaw practically all political and economic activity in the country. Over the years, as military officers retired, many of them went into business and formed a business class of elites, with close personal ties to politicians and officers still in power. ${ }^{8}$

The Guatemalan military collaborated with counter-insurgency advisors from Taiwan and Argentina to create new systems and structures for intelligence gathering. One area of focus of these efforts was the extension of control by the army, and more specifically by the Intelligence Service (S-2) of the country's customs and border control offices, ports, and airports. The goal was to stop the smuggling of arms or other materials in support of the guerrillas. This network of intelligence officers ran operations from a secret office,

\footnotetext{
${ }^{7}$ This section is based on information from a report commissioned for this study and written by Rodrigo Fernández Ordóñez, a lawyer and researcher at the Ibn Khaldun Institute at the Francisco Marroquín University in Guatemala City.

${ }^{8}$ Jennifer Schirmer, A Violence Called Democracy (Philadelphia, 1998), p. 19 as cited by the International Crisis Group, Guatemala: Squeezed Between Crime and Impunity, ICG Latin America Report No. 33, 22 June 2010.
} 
nicknamed "la oficinita," on the eleventh floor of the Ministry of Public Finance. This office assumed control intelligence over all points of national entry and egress and, during the 1980s, enjoyed a sort of institutional monopoly over the trafficking of illicit goods including drugs throughout Guatemala. ${ }^{9}$

One of the instruments the military used to gather intelligence on and control the activities of communities around the country was the figure of the civilian military commissioner, or comisionado militar, a position that dated from 1938. Military commissioners were granted their authority by the army commanders of local military zones, chiefly for the purpose of collecting information about potential local insurgent activity and recruiting local young men for military service. In practice military commissioners were the link between the army and the local population. ${ }^{10}$

Evidence from various sources, including information from U.S. Drug Enforcement Agency (DEA) reports, indicates that beginning in the 1980s, Colombian traffickers gained access to trafficking networks along key routes throughout the south and west of Guatemala. These networks were composed of military intelligence officials, their subordinates and former colleagues, and informants and partners-including military commissioners. With this collaboration, Colombian groups moved increasing amounts of cocaine through the country into Mexico. ${ }^{11}$ Also during the early 1980 s, allegations began to arise that military officials were involved in a growing range of criminal activities, including drug smuggling as well as kidnappings for ransom, car theft, and various types of trafficking. As levels of violence and anti-insurgency activity dropped, the military's pervasive economic, political and geographic presence, and its control over national intelligence, opened the institution-and several layers of the government of Guatemala-to widespread corruption and criminal penetration. Hundreds of small

\footnotetext{
${ }^{9}$ Rodrigo Fernández Ordóñez, citing Juan Hernández Pico, Terminar la guerra, traicionar la paz. Editorial de Ciencias Sociales, Guatemala, 2005, page 438. At a meeting in Guatemala City in October 2010, a former general of the Guatemalan army told CNA analysts "The nation's borders are not so big that they cannot be controlled. In the 1980s the army controlled, more or less effectively, every stretch of the border."

${ }^{10}$ Comisión para el Esclarecimiento Histórico (CEH). Guatemala: Memoria del silencio. Volumen 1, capítulo II, párrafo 426.

${ }^{11}$ According to some reports, while the U.S. DEA monitored the increase in the smuggling of cocaine and other drugs through Guatemala and the military's growing involvement, the Central Intelligence Agency approved of and even facilitated some trafficking because the proceeds in part supported the counter-insurgency activities of Civilian Patrols and other paramilitary groups.
} 
runways appeared across the countryside in the 1980s, often in close proximity to army locations and bases.

These conditions persisted and deepened even after the return to democracy in 1986. Formally, power was transferred to President Cerezo and his administration, but informally the military continued to control the country and operate with impunity against its perceived enemies in the human rights and labor movements, and within the government, including via assassinations. This control remained concentrated in the army intelligence services and the Presidential General Staff (Estado Mayor Presidencial). Notably, the return to civilian rule did not lead to significant measures to reform or rebuild the national police, an institution that had shrunk and stagnated under military rule. The new national constitution of 1985 continued the pattern from preceding constitutions in failing to provide constitutional status to the national police. By default, the army bore constitutional responsibility for the security of the nation and its citizens.

The influence of this network of former and serving military officials, and their civilian partners including former local military commissioners, was especially strong in rural areas. Historically, the attention of the Guatemala's elites and political class was focused on the capital, the key cities, and the rich agricultural and coffee zones in the Western coastal plain. As the demands of the civil war ebbed, this pattern returned. Communities in the north, north-central, and along the borders tended to have little or no contact with the national government, and local affairs were overseen largely by informal political structures. In areas of intense trafficking near or on key border crossings, highways, ports, or airports, these informal structures were necessary to provide protection to Colombians and others who required transit. The key figures in these structures or networks found such cooperation increasingly profitable and secure, under protection from military and political partners and with the lack of effective police forces.

In several cases, former military commissioners who for over a decade had been able to use their ties to the military as a means to assert their interests on local communities, were at the center of these informal structures. Along many key trade and trafficking routes, these individuals had complete knowledge and control over local trafficking, as well as judicial impunity and a free hand in the use of violence. Several of the individuals who control Guatemalan trafficking routes today, and are the targets of Guatemalan police and U.S. DEA actions, are former military commissioners, including Juancho León, Waldemar Lorenzana, and in San Marcos Juan "Chamalé” Ortiz. 


\section{The peace process and current conditions}

The first major Colombian organization to establish itself in Guatemala was the Medellín Cartel, which cooperated with and later merged with the Cali Cartel. Throughout the early and middle 1990s, Colombian groups were the dominant clients or partners of Guatemalan smuggling networks. With little fear of government or police interference and with informal structures-linked to military and government officials-overseeing operations, the system was not especially violent. This activity, and particularly the operations of the large cartels, almost certainly operated with an understanding from the highest levels of the military. ${ }^{12}$

The Guatemalan participation in this activity was limited to providing services associated with the transit of the drugs, for example: transport; contracting with local fishermen or ranchers for the use of boats, cargo space, or territory; and storage when necessary. In general, this remains true today. Guatemalan criminal organizations tend to involve themselves mostly in the transport, the provision of services related to the transport, and retailing of drugs (especially the gangs or maras in urban areas), but not generally in the purchase of raw product or its production or refinement.

In December 1996, Guatemala's civil war officially ended with the signing of a series of peace accords between the government and the umbrella guerrilla organization Guatemalan National Revolutionary Unity (URNG). The peace accords envisioned major cuts to the military and a national program to reform and rebuild a civilian police force. As various other reports describe in detail, the military was effectively cut, from approximately 44,000 soldiers in 1997 down to 16,000 in 2009. However, the reform and establishment of a professional, effective national police force was hindered by several factors including a lack of political commitment, inconsistency in administration, and a lack of consensus among elites and human rights groups regarding appropriate policing structures and models. By the early 2000s it was clear that the government of Central America's largest nation, with over 40,000 square miles of territory, over 1,000 miles of border and coastline, and over 14 million citizens, had no persistent, effective police or security presence or control in the majority of its territory.

The dominance of Colombian groups as the principal suppliers of drugs to Guatemalan traffickers diminished quickly after the peace accords. The big Colombian cartels suffered from increasingly aggressive and effective police and military actions on the part of the

\footnotetext{
${ }^{12}$ Julie López, Guatemala's Crossroads: Democratization of Violence and Second Chances. Woodrow Wilson International Center for Scholars, Working Paper Series on Organized Crime in the Americas, December 2010.
} 
Colombian government, which reduced their ability to manage international routes. Also, during the months and years after the peace accords, the dissolution of the military and its presence across the country ruptured many of the networks and relationships that had controlled trafficking for years. Local informal capos, or heads of trafficking gangs, were approached by new partners and suppliers and diversified their activities.

In 1998, Mexican cartels began to fill the void in narcotrafficking left by the retreat of the Colombians. The first Mexican groups to enter Guatemala in the late 1990s were the Sinaloa group and the Gulf cartel. By the early 2000s these two groups had established significant supply networks across the country. In the same fashion as the Colombians, these cartels paid local Guatemalan traffickers to handle transport and related services. Routes or zones, and the traffickers that managed them, were used by different cartels without much contention or violence. The Guatemalan groups, families, or networks (sometimes referred to simply as transportistas) were generally satisfied earning their modest cut and did not try to engage in other, more lucrative, aspects of the trade. In most regions, this drug trafficking occurred alongside other types of smuggling, especially of people and basic commodities (e.g., rice, gasoline), and the same trafficking networks (e.g., of drivers, vehicle refitters, police controllers, etc.) and capos were involved.

The drug traffickers' penetration into the government and police continued. In 2002 the United States revoked the visas of several Guatemalan officials for alleged ties to trafficking, and the following year the Guatemalan government dissolved the special antinarcotics unit after sixteen members were convicted for participating in extra-judicial killings. ${ }^{13}$ This problem continues to plague the government of Guatemala and its partners in counternarcotics efforts, in particular the U.S. Drug Enforcement Agency and the Department of State. There is an abundance of evidence that criminal organizations engaged in trafficking have penetrated even the highest levels of the Guatemalan military and police. ${ }^{14}$

\footnotetext{
${ }^{13}$ International Crisis Group report, page 15.

${ }^{14}$ For example, weapons clearly identified as Guatemalan military property were seized from drug cartel operations in March 2009 and in April 2009, and in February 2010 the director of the National Police Commission and the head of the government's counternarcotics unit were both arrested for activities linked to drug trafficking. Similar events, evidence, reporting, and arrests also indicate that Guatemala's judiciary, congress, and executive suffer from similar levels of corruption. See Julie López, pages 24-31.
} 


\section{Map 1: Key narcotrafficking routes in Guatemala}

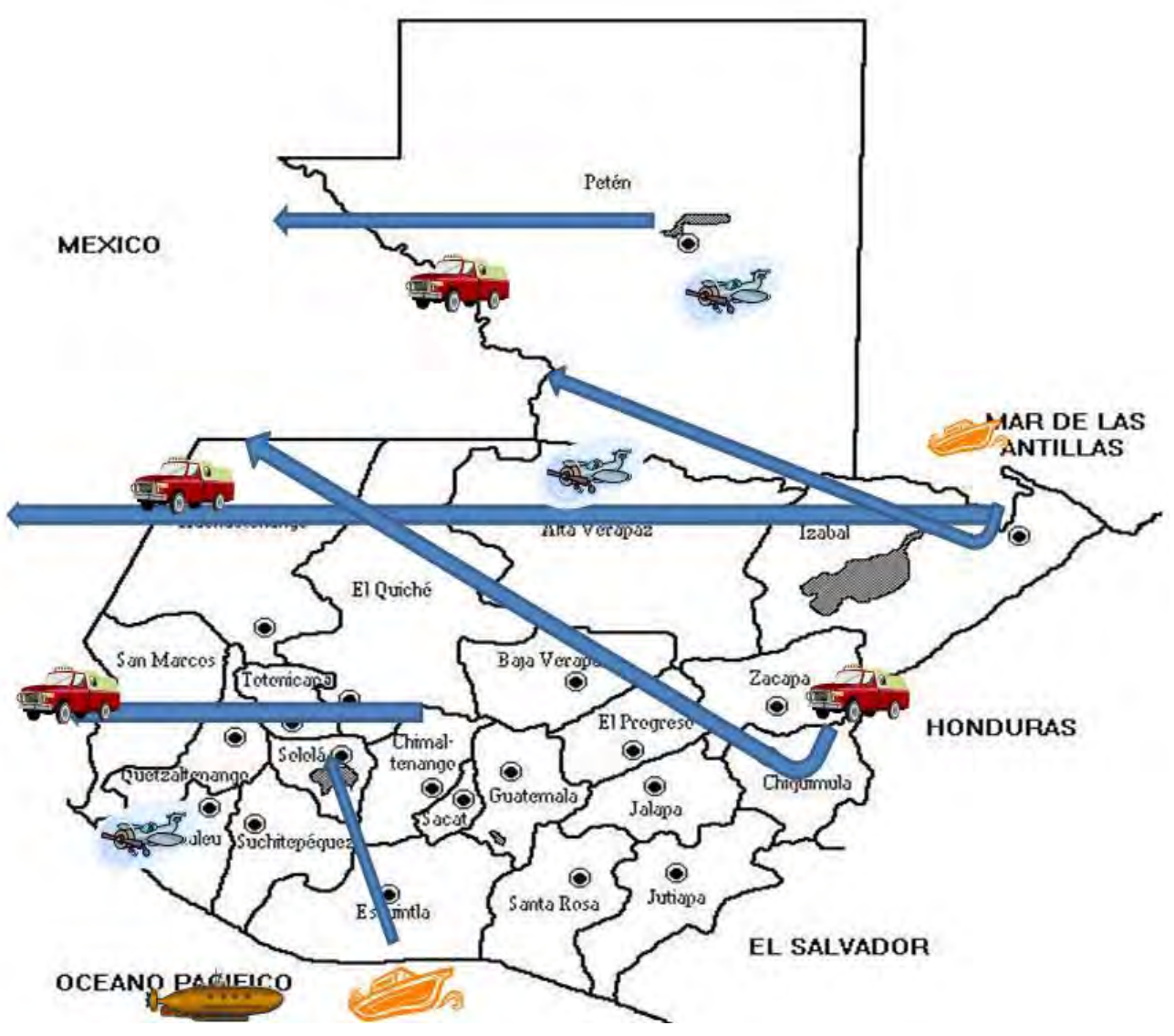

\section{8: Breakdown in the system}

The most important development regarding trafficking and its impacts within Guatemala has been the rupture of the traditional pattern of how transnational groups-Colombian and Mexican cartels_-pay local Guatemalan transportista networks. Beginning in 2008, the relatively stable system of business-like transactions between the cartels and transportistas, which had generated relatively low levels of violence, began to unravel as Mexican groups moved into Guatemala more aggressively. One of these groups, the Zetas, has introduced a new paradigm of operations and interaction with local communities, with potentially devastating impacts. 
Before 2008, the local trafficking of drugs, humans, arms, and other contraband was mostly controlled by local capos, individuals and families with a long tradition of ownership and influence within their communities. Not just criminals, capos were landowners and businessmen, community employers, benefactors, and leaders to some extent whose operations benefitted from legitimacy in the eyes of local residents. They built roads, clinics, soccer fields; they provided local citizens money for their children's parties and for medical emergencies; and-as the case studies show-they provided order and security on the streets so that residents felt safe doing their everyday business. They were able to conduct these various activities, licit and illicit, under the protection provided by their connections with military, intelligence, and government officials.

However, the stable, controlled, relatively peaceful system of trafficking in Guatemala, in which foreign groups paid Guatemalan traffickers for safe and secure passage and otherwise for the most part left them alone, ended in 2008. Part of the rupture of this system can be attributed to the arrests of top level Guatemalan transportistas. Otto Herrera, considered the chief contact for the Mexican Gulf cartel in Guatemala, was arrested in 2007, and Jorge Mario Paredes, linked to the Sinaloa cartel, was arrested in 2008. These arrests set off a series of competitions among subordinate groups and individuals, who sought to establish control over certain territories and to eliminate rivals. This caused turbulence and uncertainty across several key trafficking routes.

Also around that time, various Guatemalan transportistas began to experiment with a new tactic to increase their revenues called tumbe: the stealing of drugs in transit and their resale. By 2008, the transportista Juan José Juancho León, head of the Leon family whose operations were based in the southwestern departments of Santa Rosa and Tiapa, had gained some notoriety as a tumbedor, and other were following his example. In February of 2008, Juancho stole a shipment that was under the management of the Lorenzana family which belonged to the Sinaloa cartel. In March, he and ten others were gunned down in a military-style strike in Zacapa, along the Honduran border. The Mexican Zetas conducted the assassination, demonstrating for the first time in Guatemala their prowess as a paramilitary rapid strike force and their willingness to kill even the highest rank of capos in Guatemala. This attack was followed in November 2008 by a Zeta assault against Sinaloa partners at a horse show in the north central town of La Democracia, which left around 60 dead.

The rise of the tumbe precipitated the need for a firm response on the part of the Mexican cartels. This type of response was the specialty of the paramilitary Zeta cartel, which was originally organized and is largely trained by former special operations troops. 2008 therefore marked the breakdown of a relatively peaceful, stable trafficking system, the emergence of violent contestation over Guatemalan territory and routes between 
Mexican cartels and their local networks and partners, and the pronounced entry into Guatemala of the Zetas.

At present, this violence and contestation continues. The Zetas have managed, in a short period of time, to gain dominance over a key east-west route from Izabal through Alta Verapaz and Petén, with their operational core in and around Cobán. The Sinaloa cartel remains dominant in its traditional trafficking zones along the coast and in San Marcos. The most important zones of conflict are in Huehuetenango and Quiché, with fighting between the Zetas and the Sinaloa group, and numerous local networks and groups associated with one or the other of these cartels.

\section{Map 3: Territories of key trafficking networks}

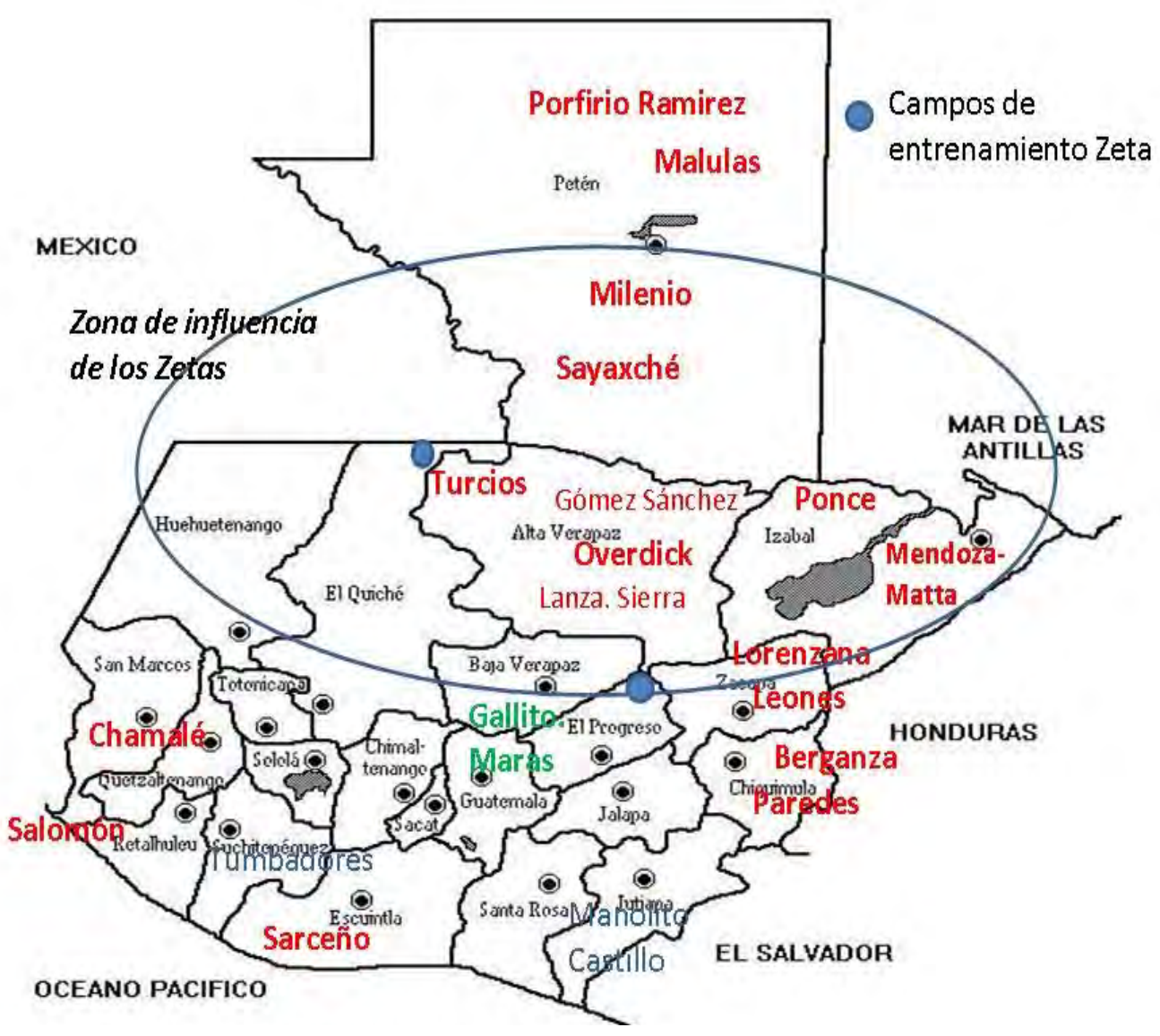

This violent struggle among the cartels creates significant danger for the traditional capos, or transportistas, who have for decades managed criminal activity in certain regions of the country. These individuals and their families face decisions whether to align themselves with one or the other cartel, thus becoming potential targets for the other, or to seek to 
continue to work neutrally for various groups. At the same time, they are under increasing pressure from the Guatemalan government, in partnership with the DEA, which has arrested several top capos in recent months. These include Juan "Chamalé" Ortiz whose operations centered in San Marcos (arrested in March 2011), Walter Lorenzana the head of the Lorenzana family of Zacapa and Izabal (arrested in June 2011), and the son and several members of the Overdick family and group (arrested in July 2011) of Alta Verapaz, who are closely associated with the Zetas.

\section{The Zetas as a new style of criminal organization}

The Sinaloa cartel and the Gulf cartel, like other Mexican and the Colombian groups who shipped drugs through Guatemala before them, operated through business-like partnerships and contracts with Guatemalan transportistas. These transportistas provided secure transport services because they had the best local intelligence regarding routes, local topography, and potential law enforcement operations. Because these transportista capos were also local community leaders and benefactors, operating through them had the advantage of maintaining legitimacy and acceptance for these activities in the eyes of the community. The legitimacy that local capos like Chamale and the Lorenzanas enjoy in the nearby communities has been demonstrated by the protection that the communities have provided when law enforcement has attempted to arrest these leaders, and the protests they conduct in their support once they have been removed. ${ }^{15}$ The Sinaloa cartel, the Gulf cartel, and others were comfortable operating through local service providers of this sort because, in their beginnings, these Mexican cartels grew similarly out of locally rooted criminal groups.

The Zetas operate differently. In contrast to other Mexican cartels, they are a criminal organization without geographic roots, and made up of individuals with no familial or regional ties upon which to base their loyalty. ${ }^{16}$ Because of their origins from Mexican special operations troops, and their emphasis on recruiting Guatemalan special operations troops, the Zetas' structure, training, and tactics are fundamentally militaryand special operations-in nature. They do not traffic product through Guatemala by

\footnotetext{
${ }^{15}$ Rosmary González, "Manifestarán en solidaridad con la familia Lorenzana” El Periodico, 24 July 2009; Oscar Herrera, "Bloqueos de carreteras en apoyo a los Lorenzana," El Periodico, 29 July 2009; Ronald Ochoa, “Caminata a favor de Juan Ortiz," La Noticia Coatepeque, 1 April 2011.

${ }^{16}$ Among the most important questions about the Zetas is how they preserve loyalty, obedience, and effectiveness within their ranks among recruits from different countries and regions.

Presumably, this too they achieve through methods that include elements of extreme violence. Evidence indicates, for example, that Zeta members tend to consume drugs on a regular basis, which is often prohibited within other cartels and groups.
} 
paying local providers and cutting deals with a patchwork of regional capos. Instead, the Zetas penetrate a region and seize control by establishing intelligence, presenting offers and threats to whomever currently traffics in the region, and committing violence-often horrific violence either in its display of firepower or its cruelty-against those who do not subordinate their operations to Zeta control. Unlike traditional criminal organizations in Guatemala which thrive in part by having the support of local communities, and operate under low risk of interference, the Zetas operate by extorting, coercing, or killing local criminal groups into capitulation and, when necessary, by terrorizing local populations into silence.

The latest example of such an act was the May 2011 massacre and decapitation of 27 workers on a farm near the Mexican border in Petén. The Zetas left messages in blood on nearby walls, written with the severed arms and legs of their victims. Strategic communication, via messages pinned to corpses, bed sheets bearing messages hung from highway overpasses, or spectacular acts of violence, are another common aspect of Zeta operations.

The Zeta organization is interesting in the context of this report because their tactics differ fundamentally from those of other, more traditional Mexican criminal organizations. The impact of their operations on local communities will also presumably be altogether different. One difficulty the Guatemalan government faces in confronting traditional criminal networks is that these networks are often run by capos with high public acceptance and support at the local level, more so than for the government itself. The Zetas present a different, perhaps less complicated, problem. In the words of local residents, one in a town outside of Malacatán, San Marcos; the other from Gualán in Zacapa:

"Since the death of Juancho, the people fear the arrival of the Zetas. Los señores and their people always say the same thing: 'You have to put up with us because we are the good guys, because the Zetas, they are indeed the bad guys.' And the people thing, 'better the devil you know..." - Owner of a restaurant in the Gualán.

"Because los señores are calm, and they don't mess with you. But the Zetas, they are bad. If they come here, we are going to end up like Ciudad Juárez," Municipal employee in Gualán. 



\section{Borders in Central America: A perennial concern}

The recent surge in news coverage regarding violence, lawlessness, and organized crime along Central America's borders would give the impression that these are new problems. In reality the problem of border insecurity has been urgently and consistently present in the national agenda for at least a decade, but with few tangible results. ${ }^{17}$

The Guatemalan government has focused its border security efforts on the border with Mexico. This border is 600 miles long and runs through 22 municipalities and 4 departments. Guatemala's 200 miles of borders with El Salvador and Honduras are less extensive, and bilateral coordination has yet to develop. There is an initiative, called $\mathrm{El}$ Trifinio or Tripoint, to improve cross-border cooperation and integration across the 45 municipalities along the border zone of Guatemala, El Salvador and Honduras, but like most other border security agreements it has had no noticeable region-wide effect.

According to official estimates, there are at least 1,200 "blind" or unobserved border crossing points along Guatemala's borders, 125 of which allow for the crossing of vehicles without any kind of immigration controls. Even at formal transit points on major highways, the infrastructure and manning of guard posts are often insufficient to provide effective control. Corruption of customs and migrations officials is also widely reported to be common. With insufficient infrastructure, limited and poorly trained personnel, and law enforcement institutions corrupted and co-opted by criminal groups, the porous nature of the borders is used to full advantage by criminal organizations for carrying out illicit transnational activities.

\footnotetext{
${ }^{17}$ For example, several Guatemalan-Mexican bilateral meetings have been held since 2005 to design and adopt methods to improve border security. Diverse initiatives to increase military presence on both sides of the border have also been launched. Later, the Colom administration announced various measures to increase military spending, deploy the Army to the northern border, enhance civil intelligence efforts, and improve coordination among the diverse security forces. However, in terms of spending and implementation, there is little evidence that these measures have had any impact.
} 
In Central America, various studies have documented the active involvement of border and coastal communities, including indigenous communities, in providing logistical support, such as storage, transport, communication, and protection, for illicit traffickers smuggling drugs, arms and human beings throughout the region. According to these studies, the isolation of these communities, their poverty, and the lack of communication and transit infrastructure enable illegal groups to corrupt local authorities and residents with relative ease. ${ }^{18}$ A report on the situation by the Institute for Strategic Studies and Public Policies (IEEPP) notes that the importance of Central America as a transfer route for international trafficking could not be otherwise explained without the surprising capacity of organized crime to capture, co-opt and integrate its operations across diverse actors within border communities across Central America. ${ }^{19}$

A recent article in the Washington Post describes the broad, cultural perception along the Guatemalan-Mexican border that in fact the border does not exist.

"To call this border 'porous' would be to suggest that there are sections which are not so. For the indigenous towns, their helpers and the smugglers that cross openly, there is no border at all. It is but a line on a map. In the Suchiate River, near the Pacific coast, the boatmen with rafts improvised of poles cross the currents, like gondoliers, transporting grains, gasoline, beer and diapers towards Mexico or Guatemala in plain sight of the authorities. The trafficking is so well established that the boatmen of Mexico and Guatemala alternate their work day schedules on the river."20

\section{Violence in border communities}

Guatemala, El Salvador, and Honduras, form what is called Central America's northern triangle, an area known to be one of the most violent zones in the world. Though Guatemala has for decades been exceptionally violent (with homicide rates typically above 30 per 100,000 people), in recent years rates of violence have been generally on the rise. As Figure 1 shows, between 2005 and 2010, the average annual homicide rate in Guatemala was 44 homicides per 100,000 residents; in 2010 it was 41

\footnotetext{
${ }^{18}$ Briscoe, I. (July, 2008). "Conflictos en la frontera: Las nuevas zonas calientes en América Latina". FRIDE.

${ }^{19}$ Meléndez, J., Orozco, R., Moya, S., López, M. (September, 2010,). "Una aproximación a la problemática de la criminalidad organizada en las comunidades del Caribe y de Fronteras”. IEEPP. p. 13.

${ }^{20}$ Miroff, N. \& Booth, W. (June 21, 2011). "In Southern Mexico, A Neglected Frontier". The Washington Post. http://www.washingtonpost.com/world/americas/in-southern-mexico-aneglected-frontier/2011/06/20/AGt74KeH_story.html?wpisrc=emailtoafriend.
} 
per 100,000 . This violence is most often attributed to a culture shaped by a weak or non-existent rule of law, widespread impunity, the legacy of decades of civil war that included the widespread killing of civilians, and-especially recently-the growing activity of organized criminal gangs and trafficking groups. ${ }^{21}$

Figure 1. Annual national homicide rates in Guatemala (per 100,000 residents)

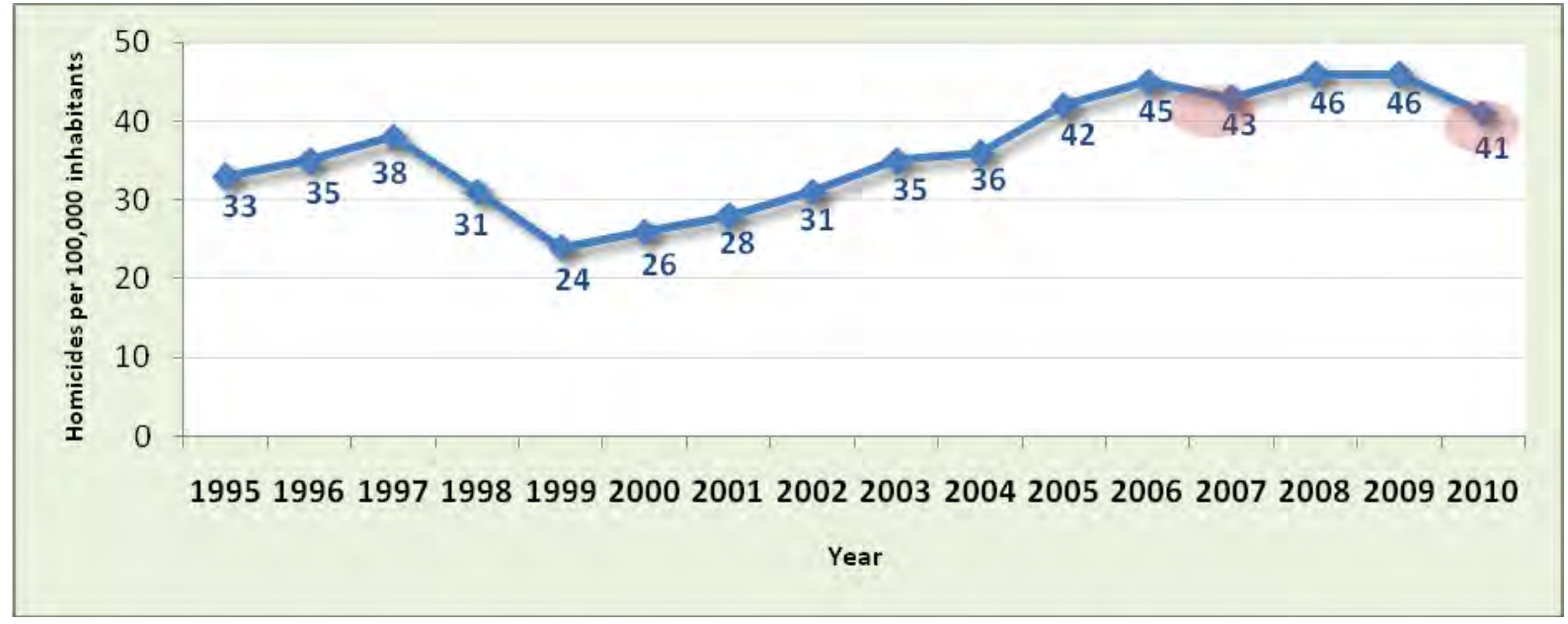

Source: Based on National Civil Police (NCP) statistics and population projections of the National Institute of Statistics. Period: 1995 - 2010.

Table 1 shows the geographical distribution of homicide rates in Guatemala in the year 2010. Of Guatemala's 22 departments, 9 greatly exceed the national average of 41 per 100,000: Guatemala (78), Escuintla (78), Chiquimula (78), Zacapa (76), Santa Rosa (66), Izabal (64), Petén (60), Jutiapa (54) and Jalapa (48).

\footnotetext{
${ }^{21}$ The explanations for the high level of violence in Guatemala vary greatly. A broad body of literature exists covering arguments ranging from the violence that followed the Coup d'Etat against Guatemala's progressive President Arbenz in 1954, to the political and inter-ethnic violence-especially against indigenous groups—which has been an increasingly intrinsic element in the culture of Guatemalan society. For more information see: Adams, T.M. (February, 2011,). "How Does Chronic Violence Affect Social Relations and Citizenship? A Survey of New Social Norms in Latin America.".
} 
Table 1. Distribution of Homicide Rates in Guatemala

\begin{tabular}{|c|c|c|c|}
\hline No. & Daprtmant & Dltitbuten & | \\
\hline 1 & crbmen & Vorhin & $\mathbf{7}$ \\
\hline 2 & Eaalinte & Hh & 7 \\
\hline 3 & 7as & Mullomhl' & 76 \\
\hline 4 & Socoteffouez & Modiumhin & 21 \\
\hline 5 & chiculmula & rwadivmhin & 7 \\
\hline 6 & 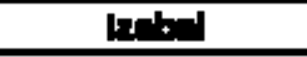 & Mandlumhli & 4 \\
\hline 7 & entracen & Mudiomhl' & 0 \\
\hline 8 & A Pre reso & Madiumhl' & 30 \\
\hline 9 & 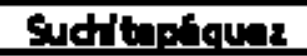 & Medlum & 39 \\
\hline 10 & Pethen & Medlum & $\infty$ \\
\hline 11 & Quetrltannso & Medlum & 29 \\
\hline 12 & 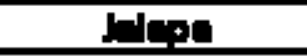 & Medlum & 49 \\
\hline 12 & wtitc & Medlum & 5 \\
\hline 14 & Eat lhulau & Madlum & 2 \\
\hline 15 & 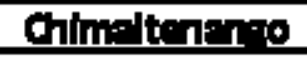 & Modlum & 16 \\
\hline 18 & Eleveris & Medinm & 19 \\
\hline 17 & & Medlum & 18 \\
\hline 19 & Ntwntest & Medlum & 17 \\
\hline 19 & Earras & Medium & 17 \\
\hline 3 & Eould: & Pudlomlow & 7 \\
\hline $\mathbf{4}$ & st+1th & redivmlay & 6 \\
\hline 2 & 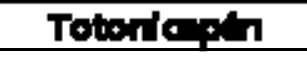 & Madiumlaw & 4 \\
\hline
\end{tabular}

Source: National Civil Police (NCP) statistics and

population projections of the National Institute of Statistics. (2010)

These statistics do not support the common assertion that border regions where drug trafficking is rampant tend to be especially violent. In Guatemala, some border departments tend to be more peaceful than average, such as San Marcos, Huehuetenango and Quiché. On the other hand, the departments along the borders with Honduras and El Salvador show extremely high levels of violence, with departments like Chiquimula, Zacapa and Izabal showing average homicide rates of over 70 per 100,000 inhabitants. However, according to Guatemalan law enforcement officials, each border zone includes specific areas and cities upon trafficking routes where levels of violence are higher, the result of drug trafficking activities. 
Table 2. Average Homicide Rate per 100,000 Inhabitants in Departments along the Borders

\begin{tabular}{|c|c|c|c|}
\hline No. & Daphinant & Bordarwith & $\begin{array}{c}\text { Homldd Fte prr } \\
10,0 \text {, }\end{array}$ \\
\hline 1 & chavimin & Eerluder & 7 \\
\hline 2 & $79+5$ & Hendun: & 76 \\
\hline 3 & latw & Hondurs & 4 \\
\hline 4 & Fat'n & Mmilco & 0 \\
\hline $\mathbf{5}$ & Jute+a & Deslods & $\mathbf{3}$ \\
\hline 6 & erincesis & Nomices & 17 \\
\hline 7 & Huchutange & Menles & 16 \\
\hline 8 & घoudh & Mingleos & 7 \\
\hline
\end{tabular}

Source: National Civil Police (NCP) statistics and

population projections of the National Institute of Statistics. (2010)

These variations in homicide rates across different border regions reflect the complexity of social and economic relations within border communities, and the differences across such communities in their relations with local and transnational criminal groups. The objectives of this report are the exploration of these complexities and the identification of the key factors that shape those dynamics.

\section{Guatemala's local political structure ${ }^{22}$}

Guatemala's local government institutions have been growing in strength since the enactment of the 1985 Constitution which recognized the need for decentralization. Previously, municipalities were weak and lacked local resources. In the more traditional indigenous communities, local officials were elected only after climbing the ladder through a series of civil service posts or religious responsibilities in the community until they could reach the position of mayor. This practice has since disappeared and election via secret ballot is the only legitimate process recognized locally.

In 2002, a national political reform and decentralization process enacted three laws which serve as a framework for the current system: The Development Councils Law, the Municipal Code, and the Decentralization Law.

Although the process has encountered obstacles along the way, the municipalities are largely the country's main sources of services, while the central government's relevance

${ }^{22}$ This section is distilled from a previous study by a member of our research team: Miguel Castillo (2009). El cuaderno de las ciudadanas y ciudadanos. Guatemala: Instituto Arpes. 
has decreased. For some observers, decentralization has opened a gateway for the installation of cartels and mafias in some regions of the country, while for others the process has opened up avenues for communities to manage and make decisions in a manner previously unknown in the history of Guatemala.

The quantity of municipal commissions created (Article 36) in these reforms is astounding: Education, bilingual intercultural education, culture and sports; Public health and social assistance; Services, infrastructure, land management, urban development and housing; Economic development, tourism, the environment and natural resources; Decentralization, municipal strengthening and civic participation; Finance; Transparency; Human rights and peace; Family, women and children.

Despite these extensive municipal responsibilities, the constitution allocates to municipalities only 10 percent of national revenues. Although the criteria used for determining disbursements has been criticized and in practice has generated accusations of favoritism (many municipalities have been discovered falsifying data in order to receive more funding), the overall effect of reform has been to increase municipalities' resources, but not by enough to make them truly effective.

For some, the negative effect of this reform has been to reduce incentives for municipalities to generate their own resources. The Guatemalan Congress is responsible for approving any increase in revenues and they discourage any effort in this regard. This highlights another contradiction in the system. The municipalities provide a large portion of public services yet they cannot exact or collect taxes for any of them. The delivery of the resources municipalities need to provide those services is negotiated politically. Municipal governments receive money in exchange for favors to members of congress and national party leaders, such as the delivery of local votes or the direction of public contracts. This underpins national and local systems of political bosses and corruption.

The lack of legitimacy or presence of the central government has led to the development of civil society in peripheral areas as an attempt to control this process. One of the vehicles (and this is one of the most original aspects of Guatemala's local structures) is a system created by the 1985 constitution which encourages the creation of civil society organizations in parallel with, and in collaboration with local and departmental government entities. These entities are the Community Development Council (COCODES), the Municipal Development Councils (COMUDES), and the Departmental Development Councils (CODEDES). The Law of Development Councils defines these councils in Article 1 as, the principal method for public participation in management and development. 
Thus, a system of councils was established, structured from the bottom up to oversee appropriations from the top down. The COCODES are autonomous citizen assemblies in which the entire community is invited to participate. These assemblies are integrated into the COMUDES, which incorporate local political authorities and finally, these COMUDES are integrated into the CODEDES, which are chaired by the country's departmental governors.

This departmental classification is one of the aspects of the local Guatemalan system which is most criticized. Governors are selected by presidents, in many cases in order to pay back earlier favors, and they lack a clearly defined constitutional function. At the same time, departments are not regions with ethnic or geographical homogeneity, which makes them fairly ineffective. To compensate for this deficiency, municipalities have embraced the model of associations to collaborate in the management of waste, water, etc., with increasing success.

Finally, the CODEDES are integrated into the National Development Council, or CONADE, which is headed by the President of the Republic and is responsible for initiating the process leading to action on petitions received.

For many critics, decentralization has become a pretext for the creation of local bosses, i.e., mayors who serve for four and five terms, although the parties may change. One can see the strengthening of the bosses in the proliferation of non-governmental organizations (NGOs), many of which seem to be employed by the municipality to carry out business in which municipal officials have private interests. For other critics, the turning of many grassroots organizations into NGOs dependent on state funding has led to a decline in their quality and an increase in corruption.

Others believe that it is a price one must pay to allow the inhabitants of each municipality to elect officials of their choice, and what should be done is to prohibit the practice known as acarreo-adding outsiders to a community's list of voters-and the use of NGOs in the construction of public works, as well as the establishment of a "second round" electoral system to increase the legitimacy of the winning candidate.

Another aspect of the dynamic described above is the influence of the Guatemalan diaspora communities in the United States, which finance many of the municipalities' services such as schools and health centers, as well as local town fairs. In many municipalities, it has become common for candidates with greater resources to do their campaigning in U.S. cities in which there are large numbers of Guatemalans. In some municipalities, the presidents of these fraternities have competed and won the race for mayor. 


\section{Case selection}

This study examines variations in the operations of criminal organizations and their relationship with local neighboring communities. Often, analysis of border regions and trafficking treat border zones as individual, consistent units. While border communities do share some characteristics (e.g., the presence of smuggling, institutional deficiencies, and economic flexibility) it is critical to recognize their differences, especially when considering policies and instruments to improve their security. Diversity among border communities suggests that in order for security policies to be efficient, they must be sensitive to and appropriate for local cultural and geographical conditions, and the social relationships and resources that exist in specific communities.

To examine this diversity, and the effects that the different characteristics of these communities have on their relationships or interactions with organized crime, we chose as the object of the investigation three cases of Guatemalan border municipalities. We decided to focus our work on the municipality as a unit of analysis, rather than the village or hamlet for example, due to the superiority, quality and quantity of data available.

The selection of the municipalities of Gualán in the department of Zacapa, Malacatán in the department of San Marcos, and Sayaxché in Petén, was carried out according to the following criteria:

- Their location along significant and often used routes for the smuggling of drugs and other contraband, and human trafficking. According to Guatemalan intelligence experts and the National Civil Police (NCP), these three municipalities are, without a doubt, important centers of operations.

- Observable evidence of the presence of organized crime. Such evidence may include, for example, incidents of violence with obvious drug trafficking characteristics; patrols in the zone consisting of men with masks and high powered weapons; new construction in the area of surprising value; and large investments difficult to explain based on the economy of the location. The three municipalities selected have experienced signs of prosperity with suspicious origins (soccer teams that compete on the national level, irregular businesses, infrastructures, etc.).

- Evidence that criminal structures in the municipalities selected have influence in local affairs. This influence may be reflected, for example, in competition with the government in areas such as security, tax collection, transit control, and employment creation, as well as the legitimacy assigned to them by the local inhabitants.

- These municipalities each present diverse characteristics based on elements of: size, location in rural or urban zones, levels of development, principal 
economic activities, and their proximity to different borders (with Mexico, El Salvador, or Honduras).

- Existing knowledge on the part of the members of the investigative team about these municipalities as well as reliable access to information regarding their economic, political and social dynamics. Types of information may include statistics and reports from municipal and federal government sources; privileged information from Guatemalan intelligence sources (one member of the investigative team belongs to the Guatemalan intelligence community); and numerous interviews in each one of the municipalities and in the capitol with security officials, police, local businesspeople, religious leaders, and community members. ${ }^{23}$

\section{Key variables}

There are numerous factors which may hypothetically contribute to the degree and manner in which a community is affected by the presence of organized crime. Based on the literature on organized crime groups and how they relate to communities and governments, especially in Central America, a combination of key factors was identified for close examination. A focus on these factors provides structure to each of the case studies to follow.

- Local Economy. The economic structure and history of a community often provides the framework for its social and political systems. With each case study, we explain the principal economic activities in the community and the manner in which they support the social, political and institutional aspects of the community. In the majority of cases, we can establish a direct relationship between the community's formal economic conditions and its informal economic institutions, including organized criminal activity. The cases differ in regard to the degree by which their criminal economies penetrate their formal economies.

- Local Political Institutions. Among the most interesting and disturbing aspects of organized crime is its capacity to prosper across a wide range of

\footnotetext{
${ }^{23}$ We do not have a complete list of the number of interviews conducted, or information about their full substance and execution. The sampling was not randomly done, but was instead based on the ability of the investigators to obtain access to officials and to solicit the opinions of officials, business owners, and people in the street. The fact that the investigation dealt with the economic, social and political effects of drug trafficking and organized crime in the communities, and not with the names or operations of the criminal groups, facilitated the work of the investigators to enter into frank discussions. Those interviewed were assured that their identities would remain confidential.
} 
relationships with local government and law enforcement instititions. Criminal organizations can intimidate governments, or corrupt them, to the point of enjoying near-total protection from government interference. Or, more frequently, criminal organizations can accommodate themselves to an independent government, co-opting key officials selectively to serve their own interests. In each case study we try to explain the balance of power between the municipal government and the local criminal networks. We also evaluate how the two entities manage their relationships. These results are especially relevant for later examination of public policies and reforms that might strengthen local governments and improve their abilities to operate in an independent manner against local and international criminal organizations.

- Social Characteristics. The norms, institutions, and cultures of local society mold the individual and collective behavior of its members. They determine the attitudes of community members towards violence and organized crime, and sentiments of collective responsibility for, and acceptance or rejection of, that violence. In each case study we identify important local social institutions (e.g., churches, civic associations, and non-governmental organizations, for example) and describe the role they play in social mobilization. We assess, as best we can from community records and recent events, each community's reserve of "social capital," by which we refer to the collective capacity of its members for self-organization in pursuit of collective benefits. ${ }^{24}$ Institutions can be effective conduits for the exercise of social capital, but social capital more specifically refers to the intangible results of that exercise: mutual trust and confidence among community members, which underpins their capacity for cooperative action.

As the case studies show, a community's social capital affects its resilience in the face of local criminal organizations. In cases where communities have a high degree of social capital, as in Malacatán, their ability to mobilize poses higher risks of interference and resistance for criminal groups. Violence in the community may be met with public demands for arrests and security and community action against group members (i.e., vigilantism). In these cases, threatening or harming the community is a high-risk, highcost strategy. Criminal groups instead seek ways of managing their relations with the community. They may, for example, try to acquire acceptance, or at least lack of

\footnotetext{
${ }^{24}$ According to Robert Putnum, who has written extensively on social capital in postindustrialized societies, ".....the term refers to features of social organization such as networks, norms, and social trust that facilitate coordination and cooperation for mutual benefit." Putnam, R. “Bowling Alone: America's Declining Social Capital”. Journal of Democracy 6:1, January 1995, 65-78.
} 
interference from the community, by providing services (e.g., books for schools, medicine for public clinics), throwing parties, or co-opting community and political leaders. As the case studies also show, this type of deterrent effect from social capital is most effective when it is combined with a local government that is skilled at working with the community. In cases where communities have little social capital, as in Sayaxché, there is a reduced threat of collective action against the criminals and the communities can be exploited, ignored, or even attacked if necessary by the criminal organization with relative impunity. ${ }^{25}$

These economic, political and social factors provide a structure for understanding the subsequent case studies. Following a review of each case, we compare them to identify similarities and differences and to seek patterns that could suggest potential areas for more effective policies or actions by the state.

${ }^{25}$ Criminal organizations also exhibit social capital because they require a certain capacity to generate trust and cooperation among the people who steal, assassinate, carry out extortion and participate in other crimes. It is for this reason that the groups are often defined in terms of a specific region or ethnicity. Our objective for this study is to use the concept of social capital to describe the qualities of our case study communities, and not to explore the multiple dimensions of this same concept. 



\title{
Sayaxché
}

\begin{abstract}
"We are going to end up like Ciudad Juarez, with the drug traffickers taking over all the businesses. If that happens there, where the Mexican government is strong, just imagine what it will be like here...The state is absent and people find work wherever they can. The business will continue and so will the violence. Oh well, the same thing is happening all over the country."
\end{abstract}

Resident of Sayaxché

Sayaxché is a relatively poor, isolated community undergoing rapid demographic change. The local government is disliked by the population and is perceived as corrupt, while few churches, community and municipal councils, and non-governmental organizations are active. Drug trafficking and activities by international criminal organizations, such as the Zetas, are growing and overlapping with contraband activities that have always been a part of the lives of the local population. However, in Sayaxché, the weakness of local institutions and of social capital means that the Zetas, the Lorenzana family, and other criminal organizations are able to operate in the region without having to accommodate themselves to the interests of the local groups, beyond the government. The presence of traffickers has some positive effects; economic growth is evident, primarily in the zones closest to the border with Mexico. Private schools are expanding as a small but growing middle class can afford to send its children to town for education. The drug traffickers also provide a certain degree of protection from common delinquency. Nevertheless, the community perceives the increasing presence of drug traffickers-particularly the Zetasand the increase in local residents who are willing to provide them with services, with a feeling of grave danger.

\section{Geography and Economy}

Petén is the largest department in Guatemala, larger than Belize or El Salvador. Its roads cut from Belize to Mexico. Its extensive, largely unpatrolled rivers and lakes connect national borders with several communities. Much of its vast airspace and territory lacks state presence or control. These features have served to convert Petén into a strategic zone for transnational criminal activities. Officials have identified 18 clandestine border crossing points for vehicles along the Mexican border; 16 in San Andrés and 2 in La 
Libertad. The Pasión and Usumacinta rivers, upon which Sayaxché is an important port, are used extensively for drug and human trafficking.

Sayaxché is a city of approximately 30,000 residents, located in the southeastern part of Petén. Because of its history as a border crossing point, the community has relatively strong ties with its Mexican counterparts. Sayaxché has seen a constant flow of migrants who arrive from all over the country, especially from the Q'eqchí ethnic group. The other significant section of the population is Ladinos who have recently arrived from eastern departments such as Zacapa and Chiquimula.

In recent years the Q'eqchí have managed to establish themselves as an influential group to the degree that in the September 2011 elections, the citizens of Sayaxché elected Rodrigo Pop, of Q'eqchí origin, as their first indigenous mayor. His principal challenge will be the technical and administrative overhaul of the local government which has been weakened by widespread allegations of corruption under the previous municipal administration. With this transition, local traffickers and criminal organizations may have lost an important ally in the previous mayor, as their relationship with the new mayor is uncertain.

Though the local economy includes small-scale trafficking, corn cultivation, and transportation and other services, Sayaxché's most important formal economic activities are the cultivation of African palm, in the municipality's southern sector and the raising of livestock in the north. The principal source of formal employment for local residents are in the four African palm businesses, which together occupy almost 30,000 hectares of land, around which have grown a number of hamlets, forming nodes of commercial activity. However, the growth of African palm production, ranching, and other services in the municipality have not resulted in a substantial improvement in the quality of life for the residents of Sayaxché and surrounding areas.

\section{Migration, land ownership and a weak economy based on a system of extraction}

Sayaxché is and has always been isolated from the rest of Petén and from Guatemala. Its population tends to ebb and flow in response to the cycles of extractive economic activity. Sayaxché today is made up of communities of unrelated origins, histories, and customs, along with new generations born locally. This diverse community is similar in one regard

in that most of its residents arrived in the rural, undeveloped region with the desire to own their own land and to rise up out of the poverty. 
Petén, in general, and Sayaxché in particular, provide examples of the pressure surrounding the issue of land ownership in Guatemala. The process of locating, assigning, and legalizing land has passed through various stages under several governments, both military and civilian, with varying policy objectives and mixed results. Over the decades numerous national institutions and programs have tried to resolve this situation, including the Guatemalan army, the Promotion and Development of Petén (FYDEP) program, the National Institute for Agrarian Transformation (INTA), the Program for the Protection of the Tropical Forests of Petén (PROSELVA), the Ministry of Agriculture (MAGA), the National Fund for Peace (FONAPAZ), and the National Land Fund (FONTIERRA). The efforts of these overlapping institutions, however, have been frustrated by the lack of common criteria for designing the selection process for beneficiaries, for technical assistance, and for the distribution of land. For example, FYDEP transferred thousands of people from Guatemala's southern coast into Petén, while FONAPAZ encouraged the mobilization of complete populations originating from the department of Alta Verapaz, principally from Raxruhá, Fray Bartolomé de las Casas, and Chisec. For its part, the army organized the majority of the current communities according to criteria based on the army's perspective, i.e. national security, and obligated displaced communities to group together in order to control their movements and to prevent them from providing logistical support to the guerrillas.

The process of land parcel identification, distribution, and acquisition was improvised and chaotic. In the southern sector of the municipality, most residents interviewed stated that they arrived in Sayaxché on their own, and that the distribution of land was carried out through informal agreements made among themselves. Later, "the institutions" arrived to make adjustments and above all, to legalize the properties.

More recently, when the African palm producers arrived and offered to buy the land, the inhabitants had not yet developed feelings of personal attachment to the land and, moreover, tended to think that it was impossible to make a profit off of the land and that it would be better to sell it. Contrary to some accounts which describe land owners as forced to sell, residents in the area speak of "a fever" to get rid of lands and to use the money gained to establish other businesses or invade land in other sections of Petén.

This uncontrolled process of land invasion or squatting, acquisition, sale, and further invasion, which continues today, facilitates illicit trafficking and crime in the area. For example, although no confirmed data exists, community leaders we interviewed agreed that the current invaders of the Laguna del Tigre Reserve come from the southern sector of Sayaxché, and that in several cases criminal groups encouraged them to invade the land to facilitate drug smuggling by burning and clearing the forest areas. A local farmer described it in the following way: 
"The land no longer produced. Various products were tried, but the land wasn't suitable, and that which was invested was lost. A few obtained a good harvest but there was no market; when the opportunity arrived to sell the recently legalized land, many people made deals....I didn't have land, but I saw how the others were selling....they were filled with dreams, they'd never seen so much money and they thought it would last forever. Some left, and others stayed, spending their money badly; now they stay farming on their land, except in reality it's no longer their land, it belongs to the palms."

A recent article, quoting the Technical Office on Biodiversity, of the National Council on Protected Areas (CONAP) of Guatemala, reported that in the Laguna del Tigre reserve, the greatest problem is the illegal extraction of lumber because "the drug traffickers clear-cut wide swaths of land in the forests to create clandestine landing strips used by planes for transporting drugs". ${ }^{26}$ According to the report, Guatemalan authorities found around 50 clandestine landing strips for small planes transporting drugs, and that community leaders supposedly paid by the drug cartels urge communities of farmers to invade and burn large extensions of the forest. In order to guard the ecological Laguna del Tigre Reserve in Petén, the army created in 2010 a 250-soldier Forest Infantry Battalion, also known as the "Green Battalion."

As time passes, the issue of local land ownership and property regulations will remain central to the drug trafficking situation and the manner in which drug traffickers operate in the region. Guatemala is a trafficking corridor, and the acquisition and invasion of land within departments is critical to the operations of criminal organizations in the region.

Drug trafficking operations have penetrated Petén through massive purchases of properties. Criminal organizations and their partners, or networks, exert pressure on the landowners of Petén and other border departments in order to take over ownership of their properties for the purpose of storing the drugs. Drug traffickers will offer a good price for the land, and at the same time suggest that refusal will most likely lead to death. Once acquired, these properties are used for money laundering through "front" activities like livestock; the construction of storage warehouses and air strips; and as spots of refuge for criminal leaders. According to one news report:

\footnotetext{
${ }^{26}$ Ordoñez, M. (May 3, 2011,). "El narcotráfico y la deforestación amenazan la biodiversidad". InfoSurHoy. http://www.infosurhoy.com/cocoon/saii/xhtml/es/features/saii/features/society /2011/05/03/feature-01
} 
"The Mendozas, who have numerous properties in Petén and Izabal, very politely obligate the land owners to leave them their farms so that they could pass through them. In the same way, one must ask the drug traffickers for permission if one wants to buy a property near theirs, in order not to disturb them. One land owner from Petén had to go to negotiate with the now deceased Juancho León in order to increase the size of his farm. León told him straight out that it wasn't in his best interest to buy that land because in one way or another the land would end up being his (León) since it was already right next to his area for moving the drugs....In other cases, the owners have been less fortunate because upon arriving at their farms, they find them already taken by the mafias which, being heavily armed and sometimes protected by the police, inhibit them from entering their own land." 27

\section{Citizenship and social capital}

The issue of social capital in Sayaxché must be considered in relation to the precarious nature of local and national institutions. Sayaxché's isolation in respect to the rest of the country and its historical and economic conditions have weakened community identity and social capital. The local authority is perceived as corrupt and inefficient. It is widely believed that the ex-mayor, Avi Maguin Cifuentes, guaranteed continuity, protection and impunity from the municipal power structure for activities related to drug trafficking. ${ }^{28}$

In addition to the mistrust between the population and the municipal government, the national government has a weak local presence and opinions expressed by community members make it clear that it too fails to garner even the slightest trust of the citizens. The national government's presence is limited almost entirely to teachers in the public schools. The health ministry has only a few community centers, and no permanent local personnel or adequate equipment. In recent years the most important and locally active entity has been the Mi Familia Progresa (My Family Progresses) program, ${ }^{29}$ which is viewed positively here as well as in other regions. Residents say that it is the first time that the national government has given them anything. However, they also complain that there is clear bias in regard to the families chosen to receive benefits from the program, as those

\footnotetext{
${ }^{27}$ Prensalibre.com (December 12, 2007). "Narcos obligan a finqueros a venderles sus propiedades". http://www.prensalibre.com/noticias/Narcos-obligan-finqueros-venderlespropiedades_0_169783972.html

28 Anonymous. (July 2011,). "Grupos de poder en Petén: Territorio, política y negocios".

${ }^{29}$ The primary objective of this program is to improve the quality of life for children under 15 years old in the areas of health, education, and nutrition.
} 
who are truly in need do not receive benefits and some of the promoters charge a commission for handing over payments or supplies.

In Sayaxché, there is no civic institution capable of mobilizing or constructing agendas to promote positive changes in the municipality and surrounding areas. The community organization COCODE is small and its leadership remains the same, in spite of the arrival of new inhabitants. In some communities, the auxiliary mayor or the president of COCODE has held those positions for more than twenty years. The COMUDE was created in 2005, but it has lost its validity due to the lack of a relationship with the municipality.

Catholic and evangelical churches are active in Sayaxché, but have little impact in civic or political affairs and are not seen as agents of change or support for the communities. The Catholic Church has a very limited number of available priests, though the Sayaxché parish is charged with mobilizing throughout all the villages, some of which are located more than 60 miles away from its center, on mostly unpaved roads. Few outside organizations provide assistance to the communities of Sayaxché. The most relevant case is the community of San Fernando, where there is a permanent project of the National Coordinator of Small Farm Worker Organizations (CNOC), which provides corn seed to each producer who commits to paying back $100 \mathrm{lbs}$. from his or her harvest. They have also provided training activities to the local COCODE and the most outstanding leaders have travelled to learn of the experiences of other small farmers in El Salvador and Nicaragua. Also, the Project Passion of the U.S. group Christian Children's Fund, visits occasionally and provides child foster care activities.

Environmental and agrarian NGO's are more active, though most of these organizations are headquartered in the central zone of the department. Most important among these is Petén's Apostolic Vicariate Pastoral Work program, which works on the diversification of export-oriented agricultural products, and offers legal advice for people and communities with land issues. The Indigenous Women's Defense Office (DEMI) also provides legal services to families.

\section{Contraband and illegal trafficking}

Smuggling has always been a part of economic activity in Sayaxché and surrounding areas. Traditionally, the smuggling of grains, sugar, and other foodstuffs has been most common, but smuggling routes and operations once established can be used to transport virtually anything. Residents report that "...everything passes [through here], not only grains." Primarily at night it is common to see several 4 x 4 vehicles with armed individuals bringing and carrying away sacks of goods, most likely drugs. The options for 
community members who live and work along the river are limited. Either they join the work of the criminal groups or they keep silent and pretend that they see nothing. One resident describes the dynamic of the drug trafficking process in this way:

"The transfer is fast because it is loaded onto big twin engine launches that head up river. Remember that the Pasión [river] goes to Usumacinta and to Mexico. Those who have become involved in that have done okay but it is risky, not because the police might catch you, as it's been a long time since we've seen an agent of the National Civilian Police, but because when another group wants to steal your shipment, you're the first ones they look for, and even if you give them information, they'll still kill you."

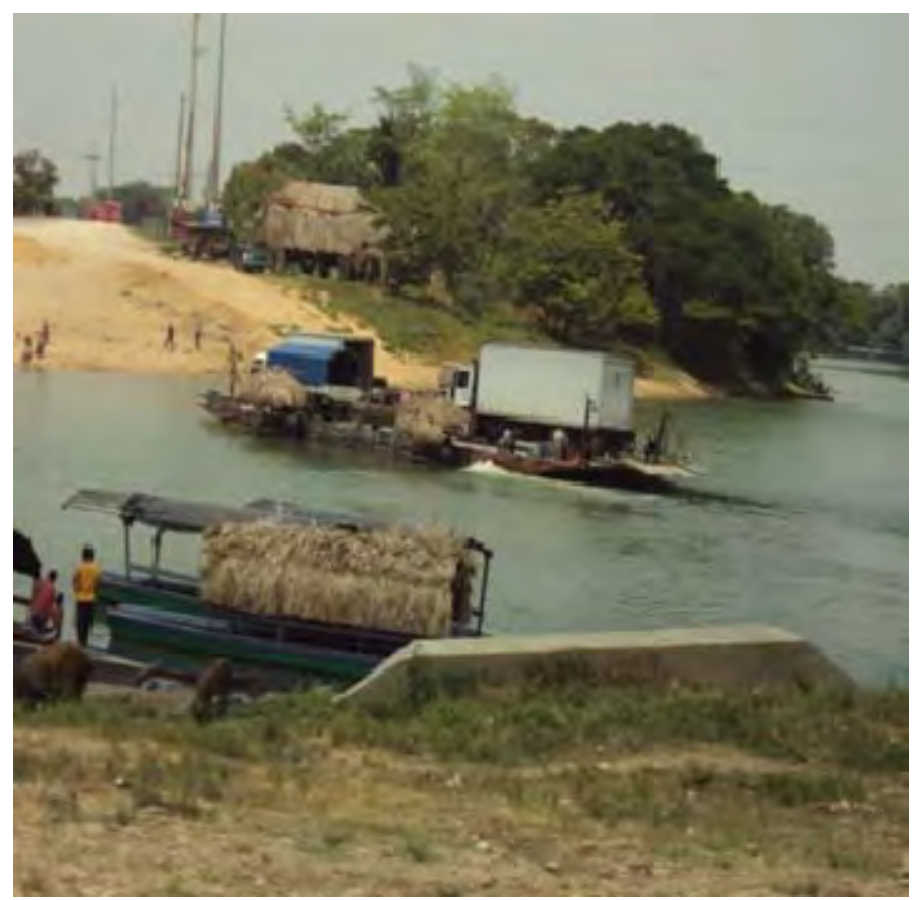

Informal crossing on the Rio de la Pasión near Sayaxché

In Petén, a complex web of interests controls all kinds of licit and illicit businesses in the region. These networks are typically based on kinship and territorial ties with a strong sense of collective attachment to the family, the tribe, the locale, and heritage. In this regard, the municipality of Sayaxché is emblematic of the partnerships or alliances that often exist among municipal authorities, drug trafficking groups, and other illegal

${ }^{30}$ Anonymous (July 2011) "Grupos de poder en Petén: Territorio, política y negocios”. Available at Insightcrime.org, or at http://isla.igc.org/GuatemlElctns/the-peten-report.pdf 
businesses-all within the context of ongoing territorial disputes and transitions between different organized criminal groups. ${ }^{31}$

As recent research has shown, the infiltration of organized crime into government structures occurs chiefly in Petén through arrangements and agreements among families, involved in local and international networks, who in this way maintain and protect local drug trafficking activities. The incentives go both ways as politicians and otherwise formal, upstanding families garner some of the profits and laundering that come from drug smuggling, and in return criminal groups receive protection from judicial or police actions. In practice, these tend not to be one-off arrangements, but rather elements of a long-term, symbiotic relationship between the department's political sector and drug traffickers. $^{32}$

In the case of Sayaxché, the relationship between the community and the activities of criminal groups is marginal. This is due fundamentally to the fact that criminal groups' relationship with and direct control of state institutions and local authorities provide them with the capacity to operate without the need for mediation from local community leaders or agents. Unlike in other cases, the criminal groups do not need protection or support for their illegal activities from local citizens. Therefore there is no particular interest in forming parallel structures with the central and local governments to provide goods and services to gain the support of the local population for their activities. Drug trafficking operations are basically business enclaves with a border mentality, which function without ties to the community.

Similarly, the inhabitants of Sayaxché and surrounding areas expect little from their legal authorities. The relationship of complicity, especially the tolerance of the National Police with and towards the criminal groups, has generated resistance from and the mistrust of the population towards the national government and local government institutions. In fact, interviews suggest a general collective perception that those who hold actual power in the area are criminal groups, with long-standing ties to political and institutional authorities.

\section{Economic and social impacts of organized crime}

For the most part, residents of Sayaxché have not seen a substantial improvement in the quality of life recent years. Nevertheless, it is possible to identify some positive trends in

\footnotetext{
${ }^{31}$ Ibid.

${ }^{32}$ Ibid.
} 
the situations of some groups and zones, which cannot be explained solely by income generated from the cultivation of African palm or sugarcane, or by contraband other than drugs. The growth of demand for private schools is one example.

Table 3. School matriculation in Sayaxché (numbers of students)

\begin{tabular}{|c|c|c|c|}
\hline If & 1994 & 2000 & 2009 \\
\hline 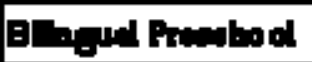 & $4 \pi$ & 586 & 50 \\
\hline Promotool & 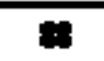 & 1,057 & 2,377 \\
\hline Ptan & 5,48 & $119 \%$ & 19791 \\
\hline 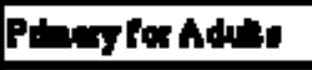 & 25 & 7 & $\theta$ \\
\hline 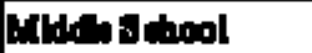 & 174 & 819 & 245 \\
\hline Hith Jhool & 0 & $\mathbf{3 3 1}$ & $\mathbf{8 4}$ \\
\hline TotAL & 6100 & 100 & 24965 \\
\hline
\end{tabular}

Source: Guatemalan Ministry of Education Statistics.

As shown in table 3, school matriculation has increased rapidly, primarily in public schools at the primary and preschool levels, as well as private schools at the elementary and high school levels. According to some, among the possible causes for the increase was the establishment of large-scale production of African palm in Sayaxché which involved a significant proportion of the population. With this new income, more residents could afford to send their sons and daughters to school. But evidence from interviews with community members and with fiscal authority officials indicate that in reality, this trend is mostly the result of collateral benefits associated with drug trafficking, primarily in the communities right along the border with Mexico.

For example, according to a boatman in the community of San José Caribe:

"Before, only the children of the large cattlemen would cross the river (Usumacinta) and go to Benemérito to study, because here there was nothing; now there are many more going to the Satellite TV high school or they cross the river. The reason? There is more money, without a doubt... All of a sudden others have arrived with pockets full of money, but we don't get involved with them because they are dedicated to transporting other things. I swear! Not all of us are involved in that, because sooner or later it ends badly. It really is better to be poor but honorable."

Officials and residents in Sayaxché point to the proliferation of private schools and university extensions as manifestations of an emerging middle class which benefits at least in part from local revenues generated by drug trafficking, but now is demanding goods 
that the Guatemalan State has not had the ability to provide. ${ }^{33}$ An educator we interviewed states it this way:

"In the municipal capitol, education has grown in recent years at an incredible rate. There is even a private school that has almost a thousand students. How is this possible? Well, for sure, the people, especially those in the border villages, have more money and can give motorcycles and cars to their kids to come here; or they send them as boarders during the week. In 'El Pato' they now have two public schools, one large and one small, but it's just that there was no longer any room, even with double sessions. It won't be long before they put in a private school because there are people who can pay for it. As you see, we already have two internet cafés and they are full all day long."

Interestingly, this new prosperity seems most pronounced in the small villages along the border with Mexico. Whereas normal contraband activity (e.g., of grains, sugar, etc.) provides only a subsistence level of profit, today's incomes in these villages seem to support full-time schooling and new construction. Community residents point to this pattern as evidence that the municipality's new, relative prosperity must be associated with drug trafficking, not traditional activity.

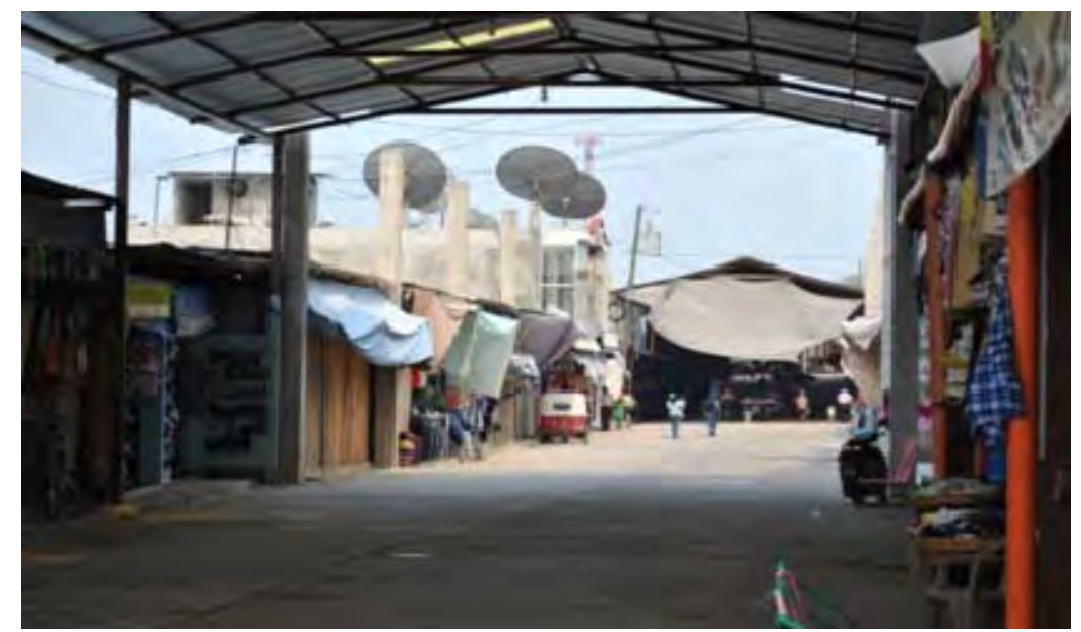

New Development - roofs, satellites dishes, new building - in a town near Sayaxché on the Mexican border

\footnotetext{
${ }^{33}$ Brodzinsky, S. (May 2011,). "Latin America's middle class grows, but with a tenuous grasp on status". The Christian Science Monitor.

http://www.csmonitor.com/World/Americas/2011/0520/Latin-America-s-middle-class-growsbut-with-a-tenuous-grasp-on-status.
} 
But the impact of drug trafficking activity on the region is not only economic. In addition to situations in which incomes from drug trafficking activity are generating prosperity, there are cases in which they also subsidize services which the state is not able to offer, such as local security. In Sayaxché, residents describe episodes of "social cleansing" by criminal groups when the need arises, particularly when gang members appear on the streets. It is a situation that, in the end, residents seem to perceive as beneficial although also worrisome. According to one local merchant:

"The presence of those people inhibits delinquency. You can see that there are very few police officers and they stay in the capitol. If it weren't for the body guards in the villages, the delinquency would create havoc."

Currently, deeply entrenched drug trafficking operations and the growing violence they produce, the incapacity of the government to respond to the situation, and the increasing presence of the Zetas, perplexes and worries the residents of Sayaxché. 



\section{Gualán}

“... the people are afraid that the Zetas may come. Los señores and their people always say the same thing: 'you have to put up with us because we are the good guys, because the Zetas, they are indeed the bad guys'. And the people think 'better the devil that you know'..."

\section{Owner of a restaurant in the Gualán}

The case of Gualán illustrates the benefits and costs of the increase in drug trafficking. Gualán is developing rapidly, especially through the production of export-ready tomatoes. It is evident, however, that much of the money is tied to drug trafficking as well. In spite of several active local civic institutions, the community's social capital is poor. The mayor is perceived to be a defender of local interests against a predatory federal government, and a supporter of the status quo, rather than a reliable leader and public servant. For decades, Gualán has seen exceptional violence, and is presently experiencing a further decline in security due to drug trafficking, even as the middle class expands. The "señores" linked to local criminal organizations have traditionally been in charge of security and of keeping the streets safe from common delinquency, instead of the police. For many in the community, they represent the best local defense against the much worse Mexican cartels, and above all, the Zetas.

\section{Geography and economy}

Gualán is a municipality in the department of Zacapa, located on a highway in eastern Guatemala near the Honduran border and the Caribbean coast. Beginning in 1961, this municipality was the scene of confrontations between the Rebel Armed Forces (FAR) and the Guatemalan Army, which was based in the municipal capitol of Zacapa and in Morales, Izabal. Beginning in 1966, many Gualantecos, accused of being guerrilla sympathizers were "disappeared" by death squads organized under the so-called Mano Blanca (White Hand) movement, presumably under the direction of a senator of that era named Oliverio Castañeda, a native of the municipality.

The Gualán region is a traditional agricultural zone, growing local food crops and, more importantly, coffee beans. However, in recent years the city has grown quickly from a 
population of around 40,000 in 2002 to more than 50,000 today. This growth has been, driven in large part by steadily increasing demand for labor in the cultivation of tomatoes and other agriculture, commercial service, and construction. The trafficking of drugs and other goods, and other criminal activity, is also perceived to be on the rise.

Gualán and Zacapa are among Guatemala's most violent cities and departments. The ownership and public display of weapons (machetes, knives, and firearms of all types), and the use violence to settle disputes, are norms deeply entrenched in the local culture. In 2010, the department of Zacapa experienced 76 homicides per 100,000 inhabitants, the third highest homicide rate among all of Guatemala's 22 departments. Gualán itself registered 85 homicides per 100,000 inhabitants. ${ }^{34}$

Trade liberalization in the 1980s hurt the region's farmers, particularly corn producers, driving them to migrate or seek other work. Until the early 2000s, the largest employers in the area were the coffee haciendas, especially those located in the neighboring municipality of La Unión. However, the critical drop in the price of coffee beans that year led to the financial ruin and closure of many haciendas, forcing a wave of families to emigrate to the United States. This situation changed the local economy, as an official from the mayor's office in Gualán describes:

"Because of the crisis, people started going to the States. People went to Los Angeles, New York, Philadelphia. In those years, village festivals were paid for by the remittances."

Remittances sparked economic growth and financial activity in the region, which introduced new irrigation systems and generated a broad shift toward the production of tomatoes on lands previously used for corn. Tomatoes became the region's principal crop. Along with the spread of tomato production in Gualán, construction of new housing has increased tremendously, including the construction of condominiums on the outskirts of the municipal capitol and in nearby villages such as Mayuelas, Shin Shin, Juan Ponce and Guaranjá.

This rise in tomato production generated a flurry of land sales and purchases. According to residents, nearly all the properties changed owners, and a high proportion of the land now is in the hands of people linked to drug trafficking who had the most resources at the time. Afterward, a production restructuring process was begun that centered on the

\footnotetext{
${ }^{34}$ According to data from the National Civil Police and population projects of the National Statistics Institute 2010.
} 
reactivated Oaxaca irrigation system. This further increased the availability of money for the cultivation of tomatoes.

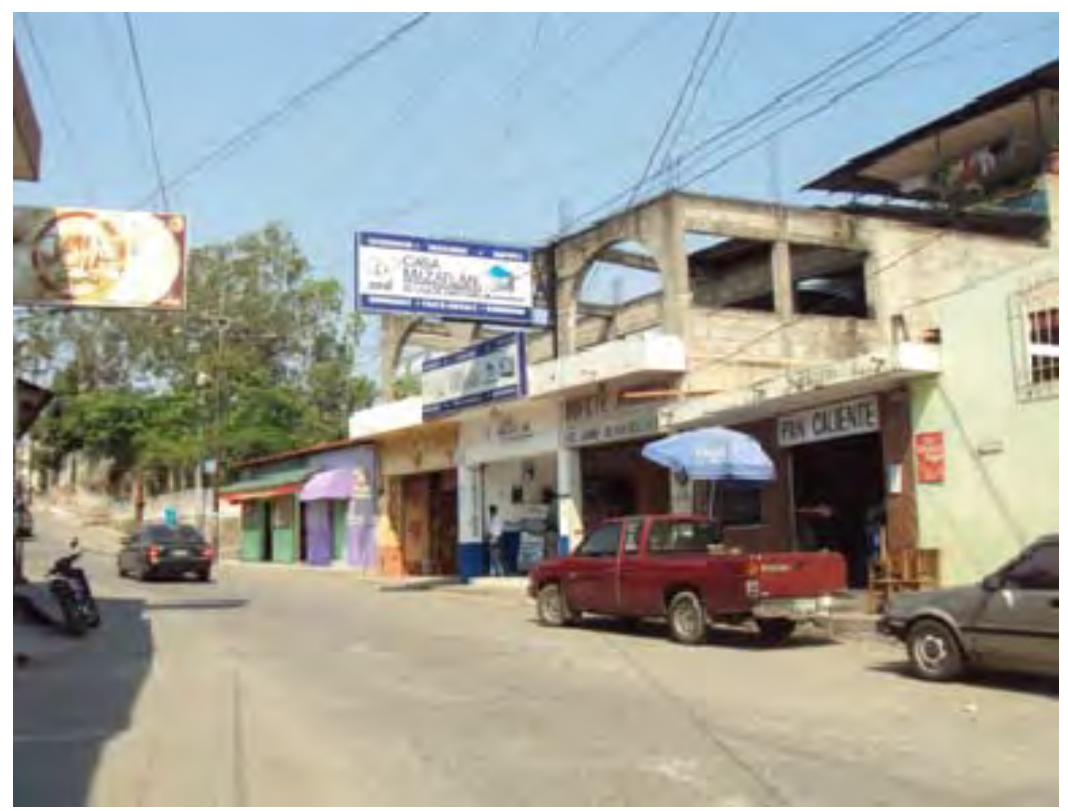

New financial services and other business in Gualán

\section{Politics and social capital in the community}

In 2001, Juan José Mejía Rodríguez was elected mayor of Gualán. He was re-elected mayor in 2004 by the Gran Alianza Nacional or Grand National Party (GANA), and later reelected for a third term in the elections of 2011. According to interviews, most citizens of Gualán rate Mejía Rodríguez's municipal management as average; the community being of the opinion that while he may not have spearheaded important projects, neither has he been involved in acts of corruption, as is frequently the case in neighboring municipalities. However, the mayor's performance must be seen in the context of a region in which local politicians generally seek some form of endorsement from the dominant drug trafficking groups (e.g., campaign financing). ${ }^{36}$ These endorsements

\footnotetext{
${ }^{35}$ At the time this investigation was carried out, there were no claims against money laundering in banking institutions in the municipality although informants think that it must be going on.

${ }^{36}$ Juan José Mejía Rodriguez's 26 year old son, Luis Fernando Mejía Monterrosa, was murdered on the road to San Juan, near Colonia El Rodeo, by individuals trying to steal his car. But as is common, many informants believe that other factors were involved in the motive and accuse the mayor of being tied to the Lorenzanas. http://www.prensalibre.com /noticias/Dan-muerte-hijoalcalde-Gualan_0_390560982.html
} 
usually entail an understanding that under no circumstances will municipal actions interfere with smuggling operations. In terms of local politics, it is almost unheard of to show opposition to the criminal groups in charge of drug smuggling. This presents a situation analogous to the traditional relationship between local governments and the economic elite in the coffee and livestock farming of Central America. In this region, according to local political norms keeping one's position in the municipal government, the administrative body of the municipality, implies understanding that one must maintain an attitude of cooperation or neutrality towards trafficking.

In Gualán, economic dynamism has not surmounted the traditional lack of organization that characterizes the municipality. The region is bereft of civic processes for consensus building, aimed at creating agendas which seek the common good. It is virtually impossible to find the issues of drug smuggling, los señores, and the effects of their related activities on citizens' security, on any kind of public agenda.

Local businesspeople may belong to the chapter of the Chamber of Commerce, but there are no analogous workers' organizations. Only three government agencies are active in Gualán, working on issues of health, education and social cohesion. There are three NGOs in the municipality: Siglo XXI (21 ${ }^{\text {st }}$ Century), Asociación Guatemala (Guatemala Association) and Corazones en Movimiento (Hearts in Motion), which carry out programs for fostering impoverished children. There is also an Association for the Protection of the Sub-Basin of the Los Achiotes River (APCRA). There are no international NGOs active in the municipality.

The most noteworthy municipal organizations continue to be those which resulted from the Development Council System: Community Development Councils (COCODES) in the villages, and more recently, the Municipal Development Council (COMUDES).

The antecedents to the COCODES in the municipality were the Pro-improvement Committees which played an important role as intermediaries between the communities and the state. As was the case in several other municipalities, the mayor and the municipal "corporation" of Gualán were reluctant players and delayed the organization of the COMUDE as much as possible for fear that it would become a source of power independent from local government structure. Ultimately, however, the municipality's need for access to international aid projects and resources-which require such a structure as a prerequisite-obligated the municipality to cooperate with the organization of the COMUDE. To date, the COMUDE has not become an independent force and its relationship with the municipal corporation is cordial because the communities find that it is preferable to get along with the municipality rather than risk losing projects and resources. The issue is seen in the following light by a store owner in the neighborhood of La Estación: 
"Although we're not free from problems, the people, especially in the villages, continue to see the mayor as the maximum authority and as the defender of the municipality in dealing with the central government. For that reason, the people support his external management. But the flip side is that the mayor has to be capable of bringing in benefits from the outside; if he can't, then he is ineffective."

The only active agricultural organization is focused on the management of the regional irrigation system and has little interest in other kinds of activities or political lobbying, even though its members are the principal beneficiaries of the municipality's economic growth.

\section{The community and contraband: "Golden tomatoes"?}

Gualán is traditionally an agricultural region, with rampant smuggling activities due to its proximity to the border. The longstanding weakness of controls on both sides of the border has helped Gualán to survive periodic crises caused by crop failures, droughts, political instability, and war. ${ }^{37}$

Trafficking is a flexible, market-driven activity. For example, Honduran subsidies for coffee production have stimulated smuggling of poor-grade Guatemalan coffee into Honduras, coffee which in turn is exported as Honduran product. Criminal activity related to smuggling drugs to Mexico is conducted on top of this fluid network of routes and service providers, as almost a natural development. Residents of Gualán and surrounding areas have learned long ago how to live with the presence of criminal networks, and there is a relatively sophisticated general understanding about the ways and means of drug smuggling and its impact on the community. It is widely understood, for example, that drug money is laundered through tomato production, in urban infrastructure, in new gas stations, in the financial system, and virtually everywhere. However, residents we interviewed asserted that no one is interested in resolving the problem. The extent of criminal activity and its contribution to the local economy and politics are well-known in Gualán and in the national capital. The authorities are well aware, but have never within anyone's memory acted against the problem beyond the occasional arrest of a drug kingpin or two. One merchant stated:

${ }^{37}$ According to one anecdote from the interviews, during the coup d'etat against Zelaya in Honduras, and before the decision of the Colom administration to close the border to local merchants, the possibility that the closure might last a long time resulted in such a high quantity of products being sent over the border into Honduras that the town was left literally empty. 
"For example, my sister works as a cashier in Mazatlán, but she had to get out fast because on one occasion she asked too many questions of one supposed client and he threatened to kill her because of it; then we realized the name was of a town in Sinaloa, and we understood what it was all about; later she told us that not all the transactions are registered. Now, you tell me if the authorities in Guatemala City don't know about this."

Interviews with departmental and city financial officers indicate that it is very difficult to determine, or even estimate, the extent to which activities connected to tomato production, urban development, and the local proliferation of private primary schools is linked to drug money. As one resident described the situation:

“...the cultivation of tomatoes has grown a lot. Perhaps this comes from money laundering, but the banks also help out as well. In these cases it's hard to distinguish legal money from bad money. But I can tell you that the majority of tomato farmers are honorable people although the money they use may not be, and although they may not necessarily be the true owners of the land."

One National Civil Police (NCP) commissioner commented on the relative urban boom in the municipality:

"Well, yes, there are many new houses that, if you look at them, you can see that they don't come from good money. Many people here are involved in questionable things, they build huge houses, God save them, but without a denouncement, we can't do anything." 


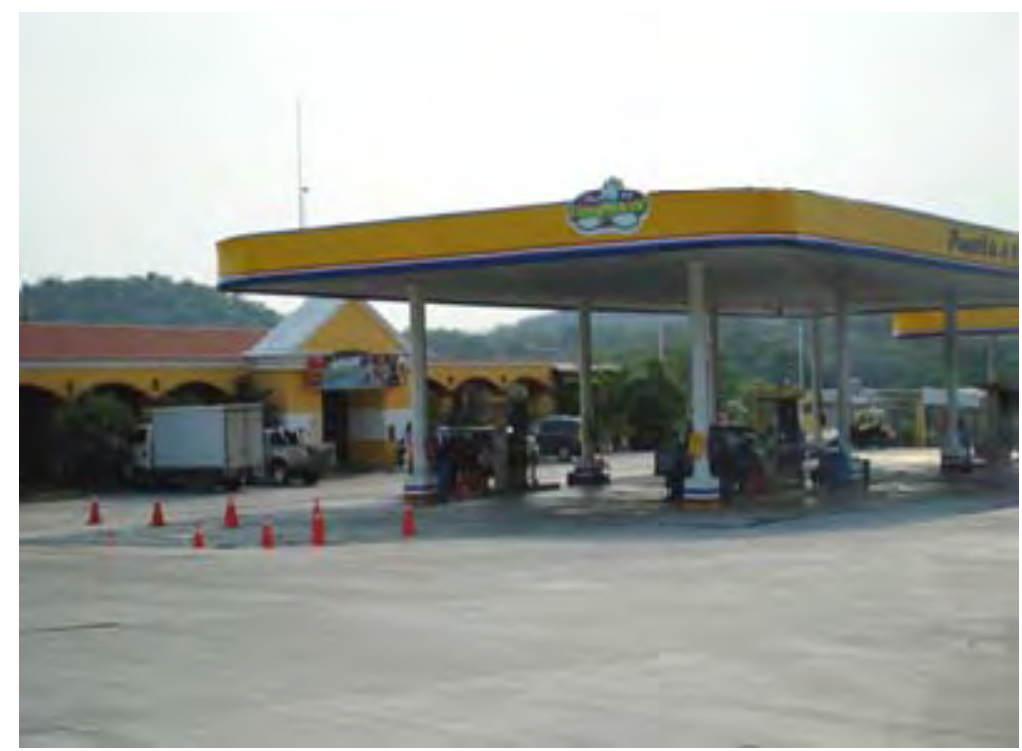

Example of new gas station in Gualán. Such stations are common means of laundering illicit profits.

The proliferation of private schools cannot be attributed solely to the activity and prosperity generated by tomatoes, or to the impact of such initiatives as PRONADE and Mi Familia Progresa. One instructor commented:

"It used to be that everything ended with primary school and very few were interested in going on to middle school. The truly rich used to go to Zacapa or to Puerto Barrios to study the last years of high school and eventually to the university. Today things have changed and almost all aspire to finish their education. This costs money and it's coming from somewhere. Before, almost no one came from the villages to study at the middle school or the private schools. Now they come in their own cars and mopeds-the very cream of the crop come in pick-ups. That's what causes all the traffic in the afternoon and the high number of eateries."

Gualán and surrounding areas have indeed seen an impressive rise in school matriculation on all levels. Over seventeen years, the school matriculation went from 6,500 students to almost 25,000 in 2009, according to data from the Ministry of Education. ${ }^{38}$ Programs such as PRONADE and Mi Familia Progresa resulted in almost total attendance for school age children. However, what stands out in this dynamic is the growth in the number of private schools for the children of people who feel that the public schools don't meet their aspirations.

${ }^{38}$ Guatemala Ministry of Education. (2007). "Anuario Estadístico de la Educación1994-2007”. http://www.mineduc.gob.gt/estadistica/2007/anuario/main.html 
Local bank officers cannot provide precise estimations about the amount to which local income and spending accounts "don't add up," but like other residents they note the clear discrepancy. As one banker in Gualán described the situation:

"Only were they to be cultivating golden tomatoes could the movement of money here in Gualán be explained. And it's not from the usual contraband because the families who dedicate themselves to that have always done so and the impact has already been established."

\section{Los señores and security in Gualán}

The emergence of drug smuggling as a central element of the social and economic life of Gualán has also implied the rise in the influence of los señores, with whom no one wants to become involved, and of whom no one wishes to speak publically. Los señores are figures from the community from diverse origins who, because of their family backgrounds (as landowners, and/or as Military Commissioners during the civil war), or political or community activism, were successful in cultivating important loyalties. Their knowledge of the community, their leadership over these communities, and in many cases their ability (and willingness) to cooperate with the military to provide security in the region during the armed conflict, provided them privileged positions as sources of intelligence and logistical operations for the smuggling of drugs. The relationship between los señores, their illicit activities, and the community is described as follows by a local police official:

"Well, what can I tell you....there is a lot of drug trafficking in the area and we can't do much about it. If you don't get involved with los señores and their people, then they don't get involved with you. For that reason, when there are operations [against them] we get worried, because los señores get angry and then take it out on us. They come and shoot up the station or the radio patrols. Up until now it hasn't gone beyond that, but one never knows... Consequently, we don't do operations without a direct order from the capitol. Not only is nothing accomplished by those operations, but one ends up getting into problems." ${ }^{39}$

\footnotetext{
${ }^{39}$ In this regard, the zone was dominated by the Lorenzano family group. Some versions revealed that particularly after the capture of the "patriarch", Waldemar Lorenzana, the rest of the gang mobilized in the mountains of the neighboring municipality of La Unión and in properties in Jocotán, Camotán and Olopa (Chiquimula), taking advantage of the proximity to Honduras, and because their roads were in very bad condition and almost impassable. In the case of Gualán, both the Lorenzano family and the collaborators or proxies had sizeable in-
} 
The perception of an economic bonanza, accentuated by drug trafficking activity, has strengthened the collective impression that "there's money" in Gualán. This helps to explain Gualán's recent increase in violent acts in the form of assaults, kidnappings, revenge killings, and mob violence. The role of the criminal networks, and los señores, is dual. On the one hand, groups fighting for control of drug smuggling routes raise the frequency and intensity of violence in the region. On the other hand, los señores and their people make some selective efforts to control local violence and crime by conducting "social cleansing" operations against delinquent groups or gangs. According to a local police commissioner:

"They say that gangs from Zacapa were behind the extortions. And they say that los señores killed three or four delinquents and the rest went away, but one doesn't really know the truth. There was a lot of talk about extortions, but we never got any formal reports. Then various kids showed up dead. They say that los señores involved in drugs killed them to clean up the zone, but as for us, it's better if we don't even get involved."

One local merchant offered a similar account:

"The number of robberies increased and the police didn't do anything. The robbers came from Zacapa or from Morales. So, people stopped going out in the street because they didn't know what might happen to them. Last year they said that los señores had established a curfew for 9 o'clock, but in reality, it was to establish order and "disappear" those responsible (the robbers)."

This social cleansing that the public attributes to los señores, in the absence of police action, seems to reinforce the local attitude that having los señores active in the community, even with their violence and criminal operations, is better than having nothing. It is not unusual for residents to express support for, or at least of acceptance towards los señores, who are after all people who were born and raised in the same community and who represent a sense of regional pride for the success they have achieved through their illicit economic activities. One municipal employee expressed the following:

"Los señores are good and they take care of establishing order. There are complications that must be put up with, but los señores are okay and they don't interfere with anyone. But the Zetas, they are indeed bad. If they get

vestments in agriculture and commerce. It is known that they are also particularly active in purchasing properties close to the borders and along the trafficking routes. 
established here, we are really going to end up like Ciudad Juarez. The problems happen when the bodyguards drink. Since they go around armed, they shoot into the air and they make a big ruckus. We, with our little pistols, cannot control them. We have to then talk with them and convince them to calm down."

A local attorney described los señores in this way:

"There has been smuggling of contraband here forever, and adherence to the rule of law is weak. Therefore, if the government doesn't come here, it is preferable to put up with the drug traffickers, as long as they assure order and tranquility for everyone." 


\section{Malacatán}

"He could be a drug dealer and whatever, but at least with Juan "Chamale" Ortiz, the delinquency was under control. Not because he was dedicated to combating crime, but because the robbers weren't keen on operating in front of the bodyguards. But now, everything is going to get out of control."

Testimony of a microbus driver in Malacatán

Malacatán is a relatively prosperous municipality with a diverse economy, a dynamic financial system, and significant commercial activity. Traditionally its wealth is derived from coffee production, contraband, coyotaje or migration services for moving Central Americans along the route to the United States, and in addition serving as the commercial center for the southern part of the department of San Marcos. Malacatán has a relatively high level of social capital, exemplified in several civic associations and interest groups and episodes of civilian mobilization. The Mayor also has a strong presence and is publically recognized for his capacity to negotiate successfully between multiple sectors of the region, including traffickers and criminal networks. The trafficking network created and directed by Juan "Chamalé" Ortiz, is typical of a criminal organization rooted in the local society and economy. Ortiz was considered a criminal, but also a shrewd businessman and a local boy made good, as well as a reliable benefactor of local churches and families in need of support. His arrest in March 2011 generated uncertainty and some anguish in the community, but as of yet it has not appeared to destabilize the preexisting criminal networks he oversaw.

\section{Geography and economy}

Malacatán is located in the southern part of the department of San Marcos, near the border with Mexico. The municipal capitol is only 390 meters above sea level with a hot and rainy climate, beneficial for growing tropical crops. The census of 2002 counted 70,834 residents, which had grown in 2010 to 86,000: an annual population growth rate of 2.5 percent. The indigenous population constitutes only 20 percent of the total population and the majority of these are of Mam origin, from the high plateau of the 
same department. Migration into Malacatán, and San Marcos in general, has accelerated in recent years due to strong economic growth.

Because of its rich soil, a range of micro-climates, diverse flora and fauna, and abundant river and irrigation systems, Malacatán has traditionally been a prosperous municipality. Traditionally, coffee producers have been the leading source of local employment; however, the industry has not regained the position it held as the principal activity in the area before the coffee price crisis of 2001, and the number of jobs that it provides has not returned to previous levels. Cultivation of African palm has been increasing in the area in terms of fields planted and permanent employment, although the total area planted is less in Malacatán than in neighboring municipalities. Although there are no local employment statistics, Malacatán currently appears to be a municipality with practically "full employment." Demand is high for unskilled labor for coffee harvesting and in the African Palm plantations. Malacatán also benefits from high quality infrastructure, by Guatemalan standards, built over the last century in response to the needs of the coffee industry.

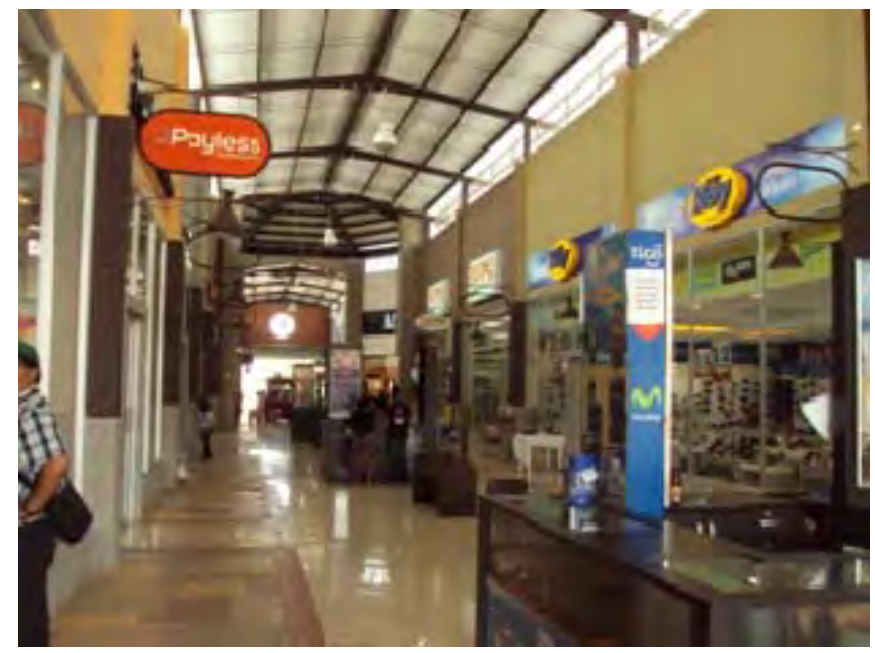

Advanced commerce and services in Malacatán.

\section{Local politics and community social capital}

Malacatán typically has a high number of mayoral candidates, a fact attributable to its considerable economic activity. In the 2007 elections, 15 candidates participated. Héctor Rubén Chávez Pérez was elected mayor and in 2011 was re-elected for a second term with broad citizen support. In contrast to the other case studies, in Malacatán residents frequently name the mayor as, without a doubt, the principal authority and leader of the region. The area's prosperity allows the mayor to dedicate himself to acting in a political role, rather than being limited to matters related only to the municipality's infrastructure. The mayor is known as the "mediator" among the diverse interest groups which exist in 
the community, such as cattle farmers, coffee growers, merchants and even drug traffickers.

Unlike the municipalities of Sayaxché and Gualán, Malacatán is not only able to provide services, but also support popular cultural and recreational activities. One example is the city's support for its candidates in the San Marcos department's beauty contests. Out of the last five contests, the municipality has won three. In soccer as well, the local team has improved dramatically in recent years and attendance and support are part of the work agendas of the local government offices. Far from marginal, these are activities to which the public pays close attention, and the involvement of the municipal government elevates its relevance in the eyes of the community.

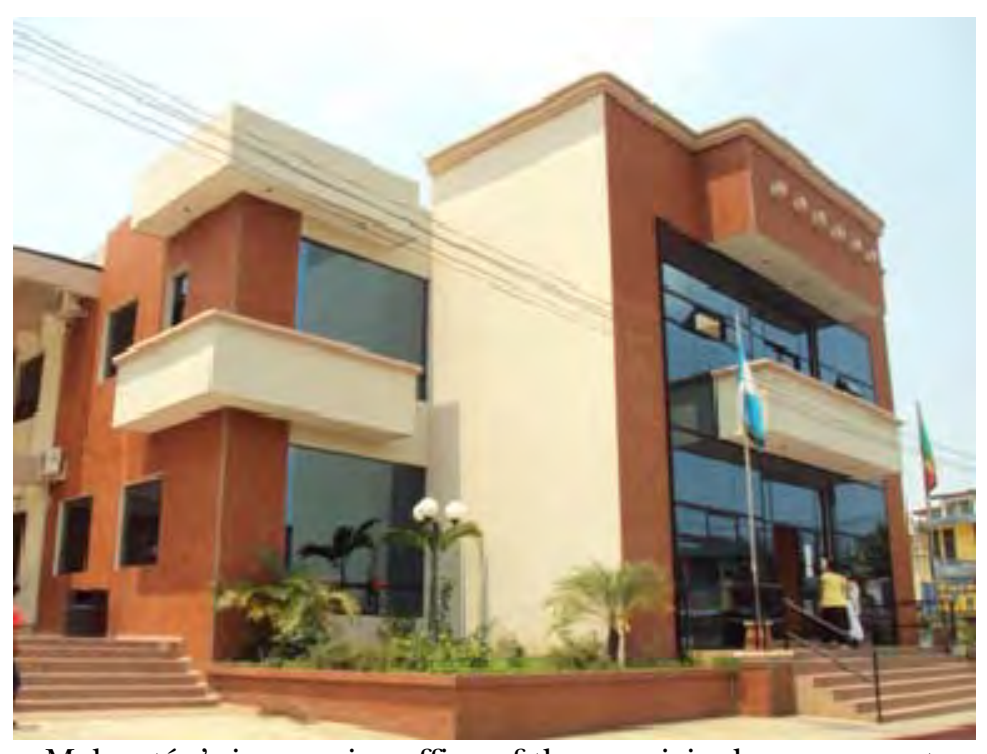

Malacatán's impressive office of the municipal government.

There are 91 communities within Malacatán, all of which have COCODES representation. The COMUDE has normal work activities and its own building for meetings and activities. In Malacatán these organizations work in partnership with local government activities.

In spite of coffee's economic importance, and the fact that several coffee plantation owners have been elected mayor, coffee producers as an economic group do not have a preponderant influence over decision making in the municipality, due to their limited degree of organization. Similarly, the African palm sector, although economically relevant to municipal affairs, remains elusive as an industry, and the owners do not tend to participate in municipal dialogues. 
With economic growth has come the rise of new entities such as sports clubs and small professional organizations, including a Chamber of Commerce. Most notable are the small farm workers' associations, which in 2008 began playing an important role in mobilization against the Western Energy Distributor (DEOCSA) in regard to local energy distribution.

Other civic associations and interest groups include the National Front for the Defense of Public Services and Natural Resources (FRENA), the health sector unions, the National Magisterial Front, agrarian entities, and small farm workers groups who were assigned farms as part of compensation programs for victims of the armed conflict. These active groups have converted the southern region of the department of San Marcos into a zone of highly motivated citizenry with multiple agendas, some of which have led to situations of protest and social and environmental conflict.

The Catholic Church has a strong influence in Malacatán, owing in large part to the leadership of the Bishop of San Marcos, Monsignor Alvaro Ramazzini, and the extensive network of pastoral workers he oversees that are dedicated to topics ranging from youth services to land ownership to opposition to mining projects. In recent years, the evangelical churches have also become more relevant as they have grown and built new churches and larger congregations. Community members seem to agree that the dramatic expansion of these churches is linked to resources provided by Juan Ortiz "Chamalé" López, the region's principal drug trafficker who is also a church pastor. It is said that these "narco-churches", as they are called locally, perform not only the function of cleansing and calming souls, but also of laundering the proceeds from Chamalé's criminal activity. However, coming across evidence or even serious investigation on the part of the authorities in this regard is not an easy task, in the same way that it is not easy to examine the claims made about links between tomatoes and money laundering in Gualán.

\section{Local trafficking and criminal activity}

As in Gualán, for many years other actors have played an important role in economic and political life in Malacatán, often acting behind the scenes. These are groups dedicated to the smuggling of drugs, products, and undocumented migrants to Mexico and the United States. Although they have no visible structure, they operate in an organized manner in terms of routes, fees, and types of products.

Those who smuggle contraband and humans are, for the most part, poor families who combine smuggling activities with other labor, such as agriculture. Some of the principal products smuggled to Mexico are sugar and clothing, while going in the opposite 
direction the demand is for chicken and eggs. This smuggling has increased dramatically in recent years. ${ }^{40}$ The visible impact of human trafficking on the municipality can be seen in the great number of hotels and eateries in the urban zone and in the village of El Carmen, at the formal border crossing. A taxi driver in the city of El Carmen Frontera commented:

"Because of close proximity with Mexico and the high taxes they always charge, supposedly to protect "national industry," Malacatán has always been dedicated to fayuca (contraband), as the cowboys say. Now, as you can see on the highway, they are smuggling Mexican Pemex gas which is subsidized, but there is also a lot of contraband of Mexican chicken and eggs. As you can see, with so much business going on in the sale of chicken, it's also being conducted on the highway, along with Camey soap and Herdez products. And with [cooking] oil? Let's not even get into it! On the contrary, a lot of corn and clothing head out as fayuca for Tapachula, Tuxtla and the rest of Mexico."

In general, these smuggling activities and those of coyotaje are separate from drug trafficking. Most residents seem to view the smuggling of normal contraband as for everybody and relatively normal, while in contrast, drug trafficking is the business of just a few and provides money to fewer people. Two local residents explained the differences the following ways:

"Mr. Chamalé is involved in drugs and money laundering. Other people handle the chicken and gasoline. In fact, smuggling spreads more money around because you can see that those who are selling gallons on the highway are poor people. Conversely, drugs, out of necessity, are the business of just the few."

"Smuggling contraband, the fayuca, has always been more significant than drug trafficking in the region. The difference between the two is that profits from contraband are distributed amongst more people and therefore it has more impact on the regional economy."

In Malacatán and surrounding areas, smuggling contraband is something that is deeply entrenched in the idiosyncrasies of the communities. As one municipal employee stated,

\footnotetext{
${ }^{40}$ Prensalibre. (2005, mayo). "Expendedores denuncian aumento de ventas ilícitas de combustible", de http://www.prensalibre.com/noticias/Expendedores-denuncian-aumentoilicitas-combustible_0_479352103.html y "Denuncian incremento de ventas de combustible de contrabando", de http://www.prensalibre.com/noticias/comunitario/Denuncian-incrementoventas-combustible-contrabando_0_478752388.html
} 
"it's something that has been there since the border was defined." In contrast to the situation in Mexico, where cartels exert control over all kinds of trafficking, there is no evidence that drug traffickers in the region are getting involved in lower level trafficking.

\section{Drug trafficking in the community}

According to city officials and residents alike, the idea that the city's prosperity might be related to drugs is erroneous, because the source of that prosperity is the dynamism of economic activity generated by the productive sector and relative well-being which, among poor families, comes from participation in smuggling. Nevertheless, various reports insist that drug trafficking has more to do with the economy of the area than local residents think, above all when trying to explain financing for the African palm industry and the dynamic of local land purchases and sales.

As in Gualán and Sayaxché, residents view the national government mostly as a predatory agent taking advantage of its minimal presence to profit in any way possible. The government is often referred to as part of the smuggling problem, due to its corruption, which via bribes and bad laws pushes the population to seek ways in which to transfer goods wherever they can, not where they should. One resident commented:

"Well, yes, there is a lot of smuggling. The borders are vast and have many crossing points, in addition to being mountainous.... The government has only the border crossing of El Carmen, and anything can get through there as well. And the customs system seems to have been designed to extract bribes from the merchants instead of trying to put order into the system. The only reason there isn't more contraband smuggling going on is because the people don't want it."

\section{The local community's relationship with and reaction to organized crime}

As observed in the municipalities of Sayaxché and Gualán, there is evidence of strong ties between criminal groups and local officials, not only in Malacatán but also in the nearby large border town of Tecún Uman. According to an interview with a former Interior Minister, Juan "Chamalé" Ortiz López had been buying the cooperation of the mayors, 
judges, attorneys and police in those municipalities for over a decade. Many also turn a blind eye to drug smuggling and other crimes, to avoid being assassinated. ${ }^{41}$

The arrest of Chamalé in March 2011 sparked new consideration about drug trafficking and its role in the economy and society of Malacatán. Attitudes in the community seem polarized. Some consider Chamalé to be the misfortune from which stem all other misfortunes, from garbage in the streets (the result of a process of diminishing values generated by the drug culture) to high rates of local delinquency. For others, "Hermano Juanito" is simply a successful businessman, who has been awarded doctoral degrees in Philosophy and Theology from unspecified North American universities, who helps the poor and who had the bad luck of running across the consumer mentality of the "gringos" and their need to justify their interventions and military-industrial complex by prohibiting consumption of products which are, in and of themselves, not harmful. ${ }^{42}$

While many drug trafficking organizations use intimidation and threats to gain access to, or control of, smuggling routes and services, Chamalés skills and practice relied more on the construction of networks of partners in the region. He built and supported this network, in part, by making donations to many churches across Malacatán and the nearby town of Catarina, where Chamalés farms and other businesses are located. This allowed the construction of several new, enormous, and luxurious churches. According to some residents, none of the local churches escaped these "donations," which to a degree bought Chamalé legitimacy in the eyes of congregation members. One Catholic educator stated:

"Well, all the churches here have eaten out of Chamalé's hands. Look at each building. With local incomes, you can't explain how they could have been built. In exchange, none of the churches said anything about him [Chamalé]. Even the Catholic Church, with Monsignor Ramazzini...kept quiet about him...”

Chamalé built his own church on the land of one of his farms. It is believed that he contracted workers for his business from among his church members, and that, in order to work in any of his businesses, one had to be a member of his church. In the end, an excess of confidence and, in the opinion of local residents, the fact that he moved away

\footnotetext{
${ }^{41}$ Noticias.com (abril 4, 2011). "Investigan nexos de Chamalé con autoridades de San Marcos". http:// noticias.com.gt/nacionales/20110404-investigan-nexos-de-chamale-con-autoridades-desan-marcos.html

${ }^{42}$ Cfr. Comments online http:/ /173.204.12.108/noticias/justicia/xela-narcotrafico- operativos_0_453554789.html?commentsPage=22
} 
from a simpler lifestyle, prompted Chamalés capture. One resident of the area explained the affair in the following manner:

"In contrast to most drug traffickers, he was a very reserved and discrete person. No luxury houses or wild parties. He seemed like just another farm owner and because of this, it was easy for him to maintain a low profile. The police, who were on his payroll, didn't bother him in the least and only those who knew him really well suspected something strange about his income. Since by that time he was a pastor, it was hard for many people to believe that he was involved in strange things. Even the tourism and recreational center he built was discrete and very welcomed by families because it was one of the few centers of entertainment in the region that didn't serve alcohol. ... Everything began to change when he met Salomón. Now, Salomón was a less refined drug trafficker: women all over the place, houses with screaming colors, large hand-held and automatic weapons, unhinged parties and luxury cars. In the beginning, Ortiz was the decent boss and Salomón was the scandalous subordinate, but little by little, Ortiz began to change. It first started with his nonsense about being a Doctor in I don't know what....but I think he didn't even finish high school. Then came all the rest: the luxury houses, latest model cars, his participation in mundane activities such as beauty pageant elections in San Marcos and Malacatán..."

Residents tell a number of stories about Chamalé: his wealth and success as a drug trafficker; his contributions to the community; and of course the reason behind his arrest. A local police commissioner describes his success in the following way:

"Juan Ortiz started his businesses 10 years ago. I don't know if he started out with opium poppies as did many drug traffickers, or if he dove right into the cocaine business. The point is, little by little he began to grow. His genius was to establish direct relationships with Mexico kingpins instead of being comfortable just dealing with intermediaries."

The arrest of Juan "Chamalé" Ortiz has generated widespread concern in the community of Gualán and surrounding areas about the violence which may result from struggles over control of the business. Without Chamalé, they fear local criminal networks may have lost the ability to control delinquency in the community, in the way Chamalé did. 


\section{Key findings from the case studies}

These case studies highlight the effects of criminal organizations and trafficking in the communities of Sayaxché, Gualán, and Malacatán. Our analysis of the comparison of the three cases suggests that the dynamics of communities' relationships with local criminal groups are influenced chiefly by three factors:

- The community's historic, economic, and geographical heritage, which create a structure for the interplay of illegal trafficking and organized crime with the rest of the community's economic and social activities and production;

- Levels of social cohesion, collective action, and civic-mindedness which favor or limit the insertion of the criminal networks into the social and economic life of communities;

- The degree to which criminal organizations, in order to operate efficiently, choose to, or must, form relationships with local authorities and community actors, as well as with actors outside of the community who have influence over community affairs.

Different levels of violence, and other negative impacts from criminal activity, can be explained, in part, as a result of the degree to which these factors are present. This is because these factors significantly affect the extent and quality of cooperation and collaboration between criminal networks and the community.

The patterns of criminal organizations' relations with local communities within these three case studies echo Enrique Desmond Arias' analysis of the phenomenon of criminality and violence in the slums or favelas of Río de Janeiro, Brazil. ${ }^{43}$ According to Arias, the reasons for violence lie not only in the lack of capacity of public institutions, but also in the nature of the contacts and relationships that criminal groups establish with civic, political and police leadership. According to Arias, "These contacts protect traffickers from state repression and help them construct political support from among the residents and favelas where they operate". In this way, criminal networks establish other networks, tying them to political and social systems within and beyond the favela,

${ }^{43}$ Enrique Desmond Arias, "The Dynamics of Criminal Governance: Networks and Social Order in Rio de Janeiro," Journal of Latin American Studies, 38, 293-325. 
rather than creating a parallel state from within. Through these connections with state officials and civic leaders, they make their criminal activities possible.

Arias maintains that, although it is evident that there are places where the rule of law functions only in part, and where judicial and police reforms can play an important role in solving the problem of violence and criminality, it is dangerous to focus only on the problems or faults of institutions while ignoring political and social relationships that promote these phenomenon and generate resistance to community reforms. Analysis that examines how criminal networks interact with other state and social actors contributes to a better understanding of current conflicts.

\section{Social capital as a community resource}

The cases of Sayaxché, Gualán, and Malacatán indicate that efficient, large-scale drug smuggling operations require at least a clear understanding of non-intervention, and at most, tacit cooperation between criminal groups and the local political power structure. This mutual accommodation seems more developed in cases of low social capital and civic-mindedness, as in Sayaxché and Gualán. In Sayaxché, criminal networks, the political structure, and most of the municipality's local elites have maintained a cooperative relationship to insure the viability of drug smuggling operations within an environment of impunity and widespread corruption. This helps to explain the fact that criminal groups in Sayaxché are less concerned with maintaining relationships and contacts with other actors in the community. They have little need for broader public acceptance of or support for their drug smuggling operations, and as a result there are few efforts to create quasi-parallel state systems to provide public goods and services.

In the case of Gualán, drug smuggling activity by criminal groups is carried out with implicit understanding and cooperation from the community. This is analogous to traditional relationships in the region between the local rural population and the landowners and overseers of coffee cultivation or cattle herds. Los señores are native to the community, and therefore there is a natural impulse on the part of community members to accept and even endorse them as long as they do not act completely against the interests of the community. Moreover, los señores are perceived to be paying back the community with goods and services, in return for their silence.

Unlike in Sayaxché, there is no clear evidence that los señores are in direct control of the local political scene. However, according to residents and Guatemalan security experts it is impossible to imagine an individual successfully gaining the office of mayor without displaying an attitude of neutrality, if not cooperation, toward los señores who not only smuggle but control, directly or indirectly, much of the municipality's land and 
agricultural businesses. Gualán displays limited social capital, but enough so that the criminal groups do not directly control local politics, and work to some degree to preserve community acceptance to insure the viability of their operations. Gualán's social capital includes generations of local families and a relatively strong, especially when compared to Sayaxché, feeling of municipal and departmental community, enough so that los señores also feel themselves to be part of the community. Their provision of local services and benefits follows a normative, as well as functional or cost/benefit type of logic.

Malacatán exhibits a relatively high level of social capital, represented in a variety of civic institutions which mobilize around demands for political and economic goods from the municipal and departmental governments. And although efforts for a dialogue to address the topic of security have been seen in San Marcos, analysts indicate that it is improbable that anyone will deal openly with the topic of drug smuggling and its effects.

Positive, collective, institutional action, a prosperous environment, and a more pluralistic, diverse local political system distinguish the Malacatán case from the others. Leaders of criminal groups must seek ways of achieving social acceptance to facilitate the sustainability of their drug smuggling activities. Therefore they present themselves as benefactors of the community, and minimize the clearly understood threat of using force and violence to protect their operations. From the community they expect, at the very least, non-intervention if not some degree of intelligence gathering and sharing. From politicians they require non-interference, impunity, and the allowance to expand their activities into other sectors of the community's economic life. As in Gualán, there is a normative as well as a cost/benefit logic to Juan "Chamalé" Ortiz's group's beneficence to the community. Chamalé grew up in the community, lived and worked openly within the community, and used his personal relationships and network-achieved through both crime and formal, legitimate ties-to further his success. So giving back to the community in part also reflects traditional Catholic and Christian values, common across Guatemala.

In Malacatán, our "best" scenario case in terms of limited negative impacts to the community from local organized crime, we learned the importance of a combination of a community with a relatively high reserve of social capital with a relatively active and autonomous municipal government This indicates that social capital is less of a good which by itself protects communities from harm, than it is an asset or reserve which responsible public leadership can utilize to help protect the community. Solid social capital alone in a community that has an incompetent or corrupted government, can do little to defend itself against criminals willing to use violence, disorder, and the withholding of key goods in order to coerce the community. It is only when social capital is engaged and mobilized by public leaders, who can provide state backing and resources, that social capital is able to create observable positive effects in terms of security. 
The dynamic of organized crime in these border regions plays out within complex geographic, socio-economic, political, and cultural contexts. Up to now the government's efforts to confront the problem of organized crime and trafficking have focused on improving the administrative management of border control operations, involving customs and immigration agencies, and the deployment of military forces to deter further violence. In order to be effective, policies to address border insecurity and organized crime must consider these border communities in their entirety, including their dynamics of long-standing accommodation and interaction among diverse local and national actors and community institutions, including local criminal groups, as all parties seek to improve their economic and political situations and indeed, stay alive. 


\section{Implications and recommendations for public policy}

These case studies highlight two factors that are important in shaping the degree to which illicit trafficking and criminal organizations affect border communities. These are political leadership at the municipal level and the extent of a community's reserve of social capital. The analysis stressed the difficulty of increasing state presence-and especially a security presence-in communities where individuals and groups associated with criminal networks offer legitimate sources of informal authority over community affairs.

The case studies indicate that where there are higher levels of social capital, and high institutional density, criminal organizations are more inclined to seek ways of ingratiating themselves with the local community. Their methods include attempting to capture social support by sharing privileges from their (illicit) success and providing public services, particularly street-level security. In contrast, in zones with little social capital and weak institutional density, criminal groups are more likely to establish relationships of control and alliance directly with public institutions. In this context, criminal enterprise is more of an enclave activity, less linked to the community and more focused on gaining the compliance of the local government.

Policies that aim at disrupting these informal networks could worsen both the security and economic circumstances in the community, unless accompanied by efforts to sustain local economic activity when the incomes and investment generated previously by criminal activity dry up. In our view, it is likely that these cases will require incremental, phased re-introduction of state services and presence, without directly threatening these longstanding networks, in order to prepare the ground for strengthened state efforts at policing and security. The critical objective is for the government (at all levels: municipal, departmental, and national) to win "the hearts and minds" of community residents so that they come to see criminal organizations and actors as unwelcome, and state institutions as competent and responsive to their needs. Essentially, border security is less about improving the capabilities of the police or border control institutions than it is about changing the attitudes and behaviors of residents who live on and near the border. The traditional and popular view that the smuggling of drugs, humans, and other contraband 
is something inevitable due to the lack of anyone to stop it and the power of the smuggling organizations to cause violence needs to be addressed and changed.

Because organized crime and trafficking operate within and throughout these communities' political, economic, and social fabrics, government strategies and policies should be holistic and include inter-agency coordination in their execution. Most likely, an effective strategy would have to be incremental, and involve a piece-by-piece reintroduction of state services and presence into these communities. Beginning, for example, with health services, improvements in schools, and better sanitation programs, could gain wide public support and legitimacy before the government attempts to wrest control over security from local señores, and directly confront local organized crime.

\section{Recent regional initiatives in border security}

In recent years the governments of Guatemala, El Salvador, Honduras, and Mexico have labeled the security situations on their borders as crises several times. They have struggled, however, to come up with the resources and institutional cooperation necessary to effect change. In Guatemala, the predominant trend has been to send army units to specific regions when violence seems to be raging out of control. For example, in response to public outcry in 2009, President Colom sent a battalion to Playa Grande, near the Mexican border, ${ }^{44}$ and in response to the April 2011 massacre of 27 ranch workers in Petén he sent in additional military units and declared the department under military orders for 60 days.

These ad hoc deployments are not the ideal response to the security problems in those regions. Providing a consistent and effective police presence capable of arresting, prosecuting, and imprisoning or extraditing those responsible for the violence, and strengthening customs and migration controls at border crossings would be much better. But President Colóm did not have a police force or another agency with sufficient resources to pursue those goals. The immediate policy choice was to send in at least the army to provide a security presence, instead of doing nothing on the ground to help its citizens, who were under seige. This pattern of sending in the military once civilian law enforcement and judiciary institutions have failed, is repeating itself in different forms in Honduras, El Salvador, and Mexico.

\footnotetext{
${ }^{44}$ Erick Girón, "El Ejército de regreso al departamento de Quiché," El Periodico, 22 March 2009 (available at: http://www.elperiodico.com.gt/es/20090322/pais/95470)
} 
The best working model for responding to "ungoverned space"is the one applied by the Colombian government in territories previously held by the Revolutionary Armed Forces of Colombia (FARC), and by the Brazilian and Rio de Janeiro police force in Rio favelas. ${ }^{45}$ While there are several differences between these cases, both basically entail integrated intervention. Aggressive, overwhelming actions by security forces to seize territory are followed immediately by coordinated, inter-agency inflows of government services (e.g., alternative economic development, health and education services) in order to hold that territory and integrate the community back into the nation's legal, economic, and political fabric. Wresting territory from non-state actors who provide informal forms of governance is not enough, if the state cannot also begin to provide these communities' fundamental needs.

Guatemala has experience with a similar initiative, the "model precinct" program conducted by the National Civil Police (NCP) with support from U.S. State Department. Since 2004 the program has trained and equipped police in special suburban and urban districts near the capital in advanced community police operations, including techniques oriented toward improving community relations. ${ }^{46}$ These efforts are combined with expanded social programs for at-risk youth to re-establish police control and reduce delinquency in poor neighborhoods plagued by gang violence. The program has had success in the town of Villa Nueva, near the capital, and was subsequently introduced in the neighboring town of Mixto.

There are several challenges to implementing these types of approaches effectively. First, they require several competent social, economic, and security government agencies working effectively together. Second, they require enormous amounts of human, financial, and agency resources, especially from security forces who must seize and control the territory. These resources must be transferred from other programs and priorities. While the security situation in the community is improving, the state must also find ways to generate new economic opportunities that might help to discourage smuggling or drug trafficking activities, as well as establish a new system of political relationships based on the rule of law.

\footnotetext{
${ }^{45}$ See Peter DeShazo, Johanna Mendelson Forman, and Phillip McLean, "Countering Threats to Security and Stability in a Failing State: Lessons from Colombia," A Report of the CSIS Americas Program, The CSIS Press, September 2009; and Adam Isaacson, "Rio de Janeiro's Pacification Program" Washington Office on Latin America (available at: http://www.wola.org/rio_de_janeiro_s_pacification_program).

${ }^{46}$ More details are available from the U.S. Narcotics Affairs Section at the U.S. Embassy in Guatemala: http://www.nasgt.com.gt/pncprogram.htm
} 
Because of the financial and political difficulty of sustaining these measures, they tend to be treated initially as if they are temporary, to last a matter of months or a year or two until normalcy is restored. But the path to economic development, sound governance through formal channels, and lasting security without well-established and functioning institutions for the rule of law, is long and in most regards unproven. So the holding of territory, and the surge in government social and economic development programs, tend to become prolonged even when restricted to a few regions. In both Colombia and Rio de Janeiro, the amount of state resources available across the government and military seems nowhere near sufficient to apply this strategy everywhere it is needed, even to relatively small sections of territory. In a country such as Guatemala, an initiative of this kind would demand an unprecedented amount of economic and human resources and would probably cover only a portion of its extensive borders.

Such approaches, coming from outside the community with a powerful range of resources, seem impractical if not impossible in Guatemala. Instead, we recommend consideration of measures aimed at mobilizing local-level resources in the form of collective citizen action, and cooperation with formal authorities, to promote security in border zones. These types of initiatives that begin from within the community, and then are supported by resources at the municipal and national level, are more likely to galvanize and utilize better local capacities.

\section{Security reform and policies pertaining to border communities}

Providing security effectively in a democratic Guatemala will require fundamental reforms and strengthening of the country's law enforcement, judiciary, and penal systems. The international community has pledged hundreds of millions of dollars to support these reforms and investments. ${ }^{47}$ These efforts are critical. However, given the difficulty of passing security reforms legislation, these foreign-funded initiatives are unlikely to lead to meaningful short-term changes. Our intent is to provide additional ideas that could help reverse the worsening trends in violence, crime, and drug

\footnotetext{
${ }^{47}$ According to the Inter-American Development Bank, international donors have given more than US $\$ 1$ billion since 2009 in grants or loans in multi-year projects to improve security in the region. At a conference in Guatemala in July 2011, U.S. Secretary of State pledged almost US\$300 million to support regional security efforts, the Inter-American Development Bank announced a US $\$ 500$ million fund for projects in the same area, and the World Bank promised to create a similar fund.
} 
trafficking in the short- and medium- terms, without compromising efforts at longer term institutional reforms.

Regarding security reforms and policies aimed at border communities, there are two overarching challenges that Guatemala must address. First, is to expand the presence of the state in those communities, in particular to introduce police units that the community views as reasonably effective and responsive. This goal seems extremely difficult to achieve within the next several years, given the slowness of Guatemala's efforts at reforming its National Police. Challenges the national police and government must overcome include the present state of dysfunction and corruption at the federal level, the skepticism and scorn of many border community residents toward the national government (which hinder cooperation with the police or government), and resource shortages that leave local police-when they are present in these communities-poorly trained, unequipped, and ineffective.

In the long run, improved law enforcement will also be insufficient to ensure security if not combined with greater state presence in other areas, particularly those like education, jobs training, and conflict mediation that help prevent crime. To objectives must be pursued more or less simultaneously: to increase state presence and control in these communities and regions, particularly in the area of security, and to broaden and improve the economic prospects for community residents.

A second critical challenge to improving security in border communities is to close the operational gap between Guatemala's federal government and its municipal government, so that the two systems communicate and coordinate strategies, policies, and spending more effectively. At present, security is entirely the responsibility of the national government, and municipal governments have a host of responsibilities and functions which very few of them have the resources to fulfill. This ignores the fact that the chronic lack of security impedes the execution of most of these other functions. The national and local governments are incapable of providing security to the communities; into this vacuum step non-state actors such as los señores who are able and willing to provide at least selective, self-serving forms of local security.

This division of responsibility for public security also ignores that the effective provision of security is multi-dimensional, involving not only law enforcement but the exercise of the rule of law and development and social welfare provisions. "Either build schools, or build prisons," as the saying goes. This longstanding lack of effective coordination between Guatemala's national and local governments-a problem the COCODES/COMUDES system was designed to resolve-profoundly impedes security policies. Some of our recommendations below are aimed at addressing, in part, this structural deficiency. 
In practice, the effective provision of security is an interrelated process. Thus, a central theme in our recommendations is to try to find institutions, channels, and instruments through which national efforts towards security, centered on improved police and military operations, may be much better coordinated with efforts, programs, resources, and demands within the country's border municipalities. Coordination across the national-departmental-municipal levels must be improved, led by security priorities and needs defined as much as possible at the local level, with complete transparency and community participation.

\section{Public policy recommendations}

We present our recommendations by theme. First, we address the issue of social capital, one of the chief factors that explains deviation in our case studies and a factor relatively amenable to policy. Second, we address the need for competent and independent municipal leadership. Beyond these thematic measures, we propose two larger reform measures which we believe would improve the capacity of the government at all levels for providing security. The first involves the creation of new structures for inter-agency coordination of intelligence and security operations, to strengthen whole-of-government efforts and improve accountability in Guatemala's border regions. The second involves raising significantly the tax revenue share that goes to municipalities, in exchange for new measures of transparency and accountability at the municipal level.

\section{Measures for promoting social capital}

Malacatán is the case study in which the negative influences of organized crime were least evident despite its well-known local operations. One of the lessons from the Malacatán case is that the area's economic diversity, including several established agricultural and industrial activities, generates a pluralistic political system in which organized crime is just one special economic interest group among others. Organized crime flourishes alongside other industries but does not dominate them, and formal economic and political activity can be conducted with little impact from trafficking-related activities that use the same material, financial, and social infrastructure. We attribute the success of the Malacatán case to a combination of factors: economic diversity, the social capital that this diversity (and other features of the town) helps to sustain, and a popular mayor who facilitates a balance among the city's different interest groups and the broader public, including negotiating with organized crime to control its local impacts. In this case, "social capital" refers to a pluralistic system where many interests are effectively articulated and coordinated by an active and diverse network of associations and institutions, and a competent and accessible municipal government. 
Gualán presents an interesting comparison where local organizations appear to be relatively weak, but social capital exists in the form of community acceptance of authority within an informal network of local landowners, business owners, and traffickers. Under conditions of economic and population growth, the community accepts (and has to accept) the benefits and costs of the illicit activity conducted locally by these local señores. Moreover, the community fears the instability and higher violence that could result if those señores were arrested or eliminated: first, because of specific conflicts that may arise between those who vie for the role of los señores and second, because initially it was the ineffectiveness and corruption of security institutions that enabled los señores to create a system of social control that brought about the elimination of any kind of insecurity or violence that was not associated with their drug smuggling operations. In this case a whole private infrastructure of security and justice was created, parallel to the inefficient, weak, and almost non-existent state system of security and justice. Furthermore, in Gualán as well as in Malacatán, los señores are widely identified as being interested and dedicated to the construction of public works and the provision of social services.

The Sayaxché case presents a dearth of social capital. There are relatively few local organizations and the ones present are relatively small and have little capacity. There is hardly any public mobilization. Also Sayaxché residents seem to express a relatively weak sense of community involvement or belonging, most likely due to the large number of transient and newly arrived members to the community. There is a widespread sentiment that not much can be done about growing levels of drug trafficking and violence. The municipal government, in addition to being weak and insignificant in the life of the community, has a history of collaboration and alliances with criminal groups.

Of the three cases studied, Sayaxché is the one in which formal public power is most controlled by criminal groups. The certainty that criminal groups are in control of the public administration system, due to what community members see as the impunity with which criminal organizations operate, has created a profound mistrust toward the judicial system and police, deepening feelings of mistrust toward the government as a whole. In Sayaxché, the alliance between institutions and criminal groups has undermined whatever legitimacy the weak state had, as well as its capacity to provide basic services to the community.

From these findings or considerations we derive the following suggestions for policies.

- Encourage local economic diversity. This encouragement can come via several policies or initiatives, and with a range of public-private partnerships, including:

o Tax incentives to investors who bring substantially different types of business into a municipal economic zone 
o Cooperating with local banks to offer lower loan rates for businesses investing in industries without an existing presence in the economic zone

o Reviewing local laws, licensing criteria, and processes which may be unnecessarily complicating the ingress of investment in new types of industries and activities

o Revision of customs legislation and procedures which promote the smuggling of basic consumer goods in border zones

- Promote the growth of local social capital. Social capital is a nebulous term referring to community members' feelings of mutual trust and confidence which arise and are sustained by networks of formal and informal associations at different levels. As Chapter 3 described, observing and measuring social capital is difficult because it is fundamentally an attitude. It is not a single behavior, attitude, or pattern, but rather a set of inter-related actions that together form a positive, local, social ecology that improves the community's capacity to act collectively. Component actions typically include: individuals' voluntary participation in local informal organizations (via churches, schools, clubs, etc.), active participation in politics, and attendance at local celebrations.

Studies indicate that degrees of social capital at the local level are slow to change, but can be developed through certain actions. One important, albeit difficult, measure to improve social capital seems to be the reduction of income inequality. Though the relationship between lower levels of income inequality and higher levels of social capital seems intuitive, the causal process is uncertain. ${ }^{48}$ Other measures can be implemented more directly, and we recommend Guatemalan municipal authorities, departmental governments, and federal agencies give them consideration. We derive these recommendations from well-known international projects and NGOs with experience at building social capital at the community level. ${ }^{49}$ These include:

o Hosting events that highlight local culture(s), traditions, and features of the community. Invite and promote active participation on the part of local organizations (e.g., churches, schools, clubs, youth groups, unions)

o Promote local events that feature dialogue about issues of local political or cultural importance.

${ }^{48}$ Anirudh Krishna, "How Does Social Capital Grow? A Seven-Year Study of Villages in India" The Journal of Politics, Vol. 69, No. 4 (Nov., 2007), pp. 941-956.

${ }^{49}$ Barbara J. Nelson, et al., The Concord Handbook: How to Build Social Capital Across Communities, UCLA School of Public Policy and Social Research, Los Angeles, California. 2003 (Last downloaded on 14 September 27, 2011: http://concord.sppsr.ucla.edu/) 
o Encourage local organizations, potentially via cost-sharing programs, to engage in voluntary public service activities. Encourage different organizations to plan and conduct such activities together.

0 Create and/or support programs that bring together different groups (e.g., different religious, ethnic, or socio-economic groups) in the community for collaboration in public service projects such as youth education, recreation, cultural celebration or development, philanthropy, etc.

- Reward and encourage effective governance at the municipal level. The case studies, particularly the Malacatán case, demonstrate the importance of political leadership at the municipal level. They also suggest, however, that such leadership is uncommon and difficult to create via policies or spending. In Malacatán a diverse, relatively prosperous community supports a mayor who works effectively across various local groups and associations, reaching negotiated solutions to common concerns, and treating criminal organizations informally like any other interest group.

In all three cases illicit trafficking thrives, but at least in Malacatán its effects on the population are modest and the political system and the rest of the local economy function largely independently from its influence. The effectiveness of the municipal government can be attributed partly to its competence and vision. However, it is also at least in part the result of the fact that Malacatán's prosperity and economic diversity led to the creation, over many years, of various associations and groups tied to special interests, a relatively rich web of local institutions with and through which a competent municipal authority can work productively.

In Gualán, however, municipal authorities operate more or less alongside informal authorities, the leaders of which are los señores and their network of legal and illegal businesses in the region. The municipal government seeks to avoid and certainly not to provoke these groups, and community residents recognize that in many aspects of their lives and especially security, they rely more on los señores than on the official government. In Sayaxché, community residents perceive their mayor and his administration as corrupt and ineffective in terms of providing public services. There are no local institutions or individuals who intermediate between the community and the criminal organizations, the most dominant of which at present is the fearsome Zetas. Community members simply try to avoid involvement, stay out of the path of these groups, and feel themselves largely at the mercy of fate. It is important to point out that in these cases the lack of both institutional density and social capital enables criminal networks to operate as economic enclaves, without close ties to the community to win their support, acceptance, or compliance. 
The degree to which we can usefully generalize from these three cases is limited; however, together these cases suggest that the greater the institutional density and social capital of a community, the less intense and constant will be the control of criminal organizations over government functions. Also, when municipal governments are able and willing to carry out visible and measurable actions in the interests of the community's well-being, community residents are more likely to perceive local criminal networks as a detriment to community affairs. In Malacatán for example, the ability of the local authority to mediate and resolve conflicts of interest among different interest groups, and its activeness in areas completely unrelated to security, dilute the influence of criminal networks in community life.

Modernization theory suggests that in Malacatán the demand for more efficient local management can be explained by a more diverse and modern economy and a society that includes a small but growing middle class, with greater resources for mobilizing around their interests. Malacatán offers some lessons for politicians interested in promoting similar processes of modernization in small, more traditional communities, as well as economic policies for attracting more investments from outside of the community.

The concept and practice of an "effective government"are factors which defy objective measure, even more so when our measure of effectiveness includes success in managing the local presence of drug traffickers, for the purpose of limiting their negative effects. For example,, if conflicts related to drug smuggling groups are not resolved, many Guatemalans will consider the management of community interests a failure. Thus, the subject of rewarding or encouraging specific policies or results in the local environment through national programs, could certainly become politicized, above all when it is assumed that the municipal work effort must be aligned with national government policies. Therefore, rating and encouraging the municipal initiative are actions which must come from non-partisan organizations independent of state institutions. ${ }^{50}$

A review of possible approaches for creating incentives for more efficient management on the municipal level produced the following policy recommendations:

\footnotetext{
${ }^{50}$ One such organization, for example, is Transparency International, a global network that combats corruption world-wide, bringing together actors from government, civil society, commerce and communications media to promote transparency in elections, public administration, hiring and business. Through local partners, they rate and highlight municipalities which have made efforts to improve municipal accountability and to prevent corruption.

Http://www.transparency.org/about_us.
} 
o The promotion of rules and instruments that improve transparency and accountability, so that residents and others are more aware of what the government is doing.

o Recognition by an objective, non-partisan organization with public credibility of mayors and/or municipal governments that are judged to be particularly "effective" at building social capital, or improving citizen security.

\section{Security zones and other measures to improve inter-agency security operations}

Public policies oriented toward improving the state's performance in dealing with organized crime in border communities require institutional reform processes that are consistent, coherent, and simultaneous on national and departmental levels. It is difficult to achieve effective, professional police services at the local level without a consistent, successful, police reform process at the national level. It is also difficult to create comprehensive policies for approaching the problem of drug trafficking without reforms which strengthen coordination and cooperation between agencies. In spite of the challenges involved in local policing and security reform efforts, it is essential to reform public policies in order to provide flexibility for the government in acting in socially and economically complex border regions.

We encourage the efforts underway, and the consideration of other methods and reforms to increase the presence of a well-functioning and responsive state in border communities. These reforms are, or should be, advancing on several levels:

- Define, advance, and strengthen the program for the reform of the National Civilian Police

- Clarify the army's role in providing security to the population and border security;

- Implement joint inter-agency efforts to confront organized crime, including the creation of special security supervisory groups with a flexible, inter-agency framework in regions where criminal organizations operate

\section{Police and institutional reform}

It would be helpful, if not necessary, if the government would clearly define the objectives of Guatemala's police reform process and how these objectives and their expected results relate to security policies and operations in border communities. The reform process must clearly indicate the role of national police in border communities and define police action in relation to the increasing military presence in border zones. It is important to keep in mind that the National Civil Police (NCP) has very limited authority and 
legitimacy in the eyes of community members in the communities studied. Although the Guatemalan constitution makes reference to local police entities, currently there are no clear efforts to establish such systems.

Police reform is an undertaking both technically and politically complex. Powerful forces strive constantly to undermine efforts to improve police performance, and to reverse previous advancements. Still, such reforms are essential for national and citizen security, and must proceed based on fundamental principles. In our view these efforts should include:

- A clear statement from the president and his chief law enforcement officer which defines the functions and authorities of the NCP and its relationship with the citizenry;

- An explanation of what parts of the reform process have been inefficient in their execution, and why;

- A defined system of internal promotion and career paths within the NCP, one that that makes full use of and provides incentives for hard work and talent;

- The improvement of the police training and professionalization process;

- Measures to ensure internal and external transparency and accountability.

In addition, three possibilities should be discussed publicly, and considered by the government, in a serious and non-political manner: 1) a reform of the security sector which, for example, could result in the creation of a border guard; 2) the redefinition of the model and role of the army in their fight against drug trafficking and other expressions of organized crime; 3) the recuperation of local police institutions, the lack of which clearly affects the capacity of communities to respond to local crime and insecurity, allowing criminal organizations to introduce their services and replace the state.

The absence of a non-political debate has resulted in the overuse of military force in dealing with security problems in border communities. Given the state's limited resources, the viability of these policies is ever more uncertain. In our view, in Guatemala today, there is inadequate public discussion about the costs involved in the implementation of the peace accords, referring to those initiatives that dismantled the military without first creating an effective civil security and law enforcement system. These policies and failures created numerous incentives and opportunities for traffickers and organized criminal groups to exploit Guatemala as a drug smuggling zone.

Guatemala requires a serious and open public discussion, led by its government but including civil society, about the kind of army the country needs. Opinions vary on this subject, and sentiments are intense given Guatemala's recent history of civil war and 
corruption within the military. There are influential sectors of Guatemalan society that see the army as the institution best prepared to confront challenges related to security and the fight against organized crime, especially when dealing with the control of airspace and national borders. There are also equally influential sectors that are concerned by the deployment of the military to confront organized crime activities, given the current inexistence of an institutional environment of transparency, civilian control, and accountability in Guatemala.

\section{Measures to implement joint inter-agency action}

The provision of security in border communities is complicated by the lack of integrated national, regional, and local efforts and information sharing. When the presence of national security forces is minimal, this leaves municipalities to face criminal organizations and other threats largely on their own. We recommend consideration of a set of legal and institutional reforms that would restructure the territorial divisions in which national security policies are implemented, creating what could be called "special security zones." These would be geographical areas administrated by working groups or task forces that include members from different state agencies (e.g., police, military, health) and civilian institutions (e.g., security think tanks, NGOs). These task forces would collect and integrate information on organized criminal operations from the police and municipalities across the zone, analyze this information, and choose the most appropriate anti-trafficking and anti-organized crime policies and tactics for the zone. An initiative of this nature would require open communication, coordination and clear measures for oversight and transparency at the levels of both national and local government. One of the fundamental objectives of creating these special security zones would be to promote the responsible use of public resources. ${ }^{51}$ By integrating the expertise and professional experience of officials from civil society and across various state agencies, these councils would bring resources and know-how to border communities which at present lack any such support from outside.

Such a system would improve vertical and horizontal information sharing and coordination between actors at the national and local levels and across a range of stakeholders, including government agencies, to increase capacity for designing and administering public policies for enhancing economic and human security. The

\footnotetext{
${ }^{51}$ This complementary mechanism would strengthen good practices of progressive "deconcentration" and "de-centralization" which have been proposed and launched in civil regulations and practices in Guatemala's recent past, to provide more relevance to the local environment; a subject which is explicitly included in the peace accords of 1996 and continues to be a constant since then with disparate results.
} 
government would be made more present across its national territory, and more effective because of its increased capacity for integrated inter-agency actions. These task forces would bring together a wealth of public and private experiences developed over many years by people working in and for border communities in areas including environmental, commercial, public, and security services. These groups would also benefit from the full participation of local governments. This could include community participation, based on models from the existing, diverse, participatory experiences at the community level in Guatemala.

The multi-disciplinary nature of these task forces would be a key element of their value to the government and, more broadly, the national political system. ${ }^{52}$ They could include officials from the government, the army, the NCP, and local police, as well as civil society actors. Through this joint effort, several institutions together-public and private, national and local-would share responsibility for seeking solutions to the diverse problems of security confronting border communities in Guatemala.

\section{Improving citizenship and social capital by increasing the resources and authorities of local governments}

Ultimately, what is required to control the impact of the criminal organizations and illicit trafficking in the border communities is an increase in the active and effective presence of the state in these communities, properly integrated with and in support of community institutions. It is clear that expansion of the legitimate presence of the state will be difficult under any circumstances, especially when faced with limitations related to scarcity of financial resources, in a country with critical needs such as Guatemala. But it is also clear that the reform process could streamline the use of some resources currently being misspent, to reduce the vulnerability of the country in the struggle against organized crime.

It is our opinion that the potential for expanding the presence of the state is relatively easy to imagine in cases similar to Sayaxché, where the social and political infrastructures are minimal and the needs are great. Isolated and underdeveloped communities like these would most likely welcome any future efforts by the government that would lead to

\footnotetext{
${ }^{52}$ The incoming Guatemalan President Pérez Molina described, during the presidential campaign, a similar idea for the establishment of "Inter-Institutional Task Forces (FTI),"which would consist of personnel from the National Security System, with the support of the Attorney General's Office and the Federal Human Rights Office. Each Task Force would be assigned a geographic area where they would combat the principal crimes: drug trafficking, drug dealing, extortions, assassinations and gangs. In each of these areas, civilian organization will be promoted, to facilitate the recuperation of public areas and to sustain community security.
} 
providing services. However, long-term, sustainable improvements in these communities' security will require more than additional troops or police. Citizens must gain social capital by developing the capacity for cooperation and trust first among themselves, and second in coordination with and support of government initiatives.

In Malacatán, there are also various options for incrementally increasing state presence with the support of the community. The local government, private sector and actors from civil society exist in abundance and would likely be interested in reaching agreements with public institutions that would allow for coordinated efforts toward increasing state presence. As the case study showed, organized criminal activity in and around Malacatán takes place within a broader, stronger legal economic environment. National agencies would be welcomed within this formal sector for the benefits they bring, and would pose no danger to most of Malacatán's society and economy.

However, it appears that cases such as Gualán present the greatest challenge due to ageold patterns of services provided by entrenched traditional groups like los señores and the greater relative importance of trafficking and related activities to the local economy. In such cases, popular support for these groups and profound mistrust of the Guatemalan government could cripple efforts to alter these long-standing dynamics and curb criminal activity in the area. The community will be suspicious, and skeptical, and is likely to rally around local institutions and associations, at least at the beginning. Success will require patience and a cautious strategic approach via the early insertion of non-security agencies such as health, sanitation, and public works. A greater share of resources will likely be required before national institutions and, eventually, state security forces gain acceptance and collaboration in these communities.

\section{Fiscal decentralization as a long-term consideration}

Our case studies consistently demonstrate that residents of border communities tend to view the Guatemalan national government as unhelpful at best, and predatory at worst, and at any rate unworthy of their trust. For this reason, we suggest for consideration that the most effective, short term course of action must be policies and programs designed at the local level, with input but not firm guidance from institutions of the central government. The Guatemalan government should increase its presence largely via the strengthening of local, municipal entities and particularly the reserve of social capital with which they can work, so that the communities themselves may be effective coordinators of the process of improving local security.

Clearly, part of strengthening the capacities of local governments relates to improving their access to economic resources, to allow them to supply services demanded by the community. In our view, Guatemalans should reflect seriously on their tax structure. Not 
only-as is often stated within Guatemala and by outside observers-does the central government need far more resources for its security institutions, reforms, and operations, but local governments also need greater resources in order to serve the needs of their communities. Reforms along the lines of fiscal federalism, by which municipal and departmental governments collect and spend a greater share of total taxes (their current share of total public spending is fixed, constitutionally, at 10 percent), would place greater responsibility and resources on local governments. ${ }^{53}$

A more decentralized tax system would help increase the autonomy of local governments and improve the institutional capacities. By strengthening the autonomy and effectiveness of local governments, their legitimacy in the eyes of the community will improve as well. Bringing state institutions and policymaking closer to the citizens they serve improves government performance. As more citizens see government as beneficial instead of detrimental to their welfare, citizen support and involvement would likely increase. By providing incentives for citizens in border communities to be more active in their local politics and in their communities in general, decentralization or fiscal federalism could improve the quality of Guatemalan citizenship, and social capital.

However, given the mixed, and in many senses negative experiences with decentralization in Colombia, Mexico, and other Latin American countries (where the penetration of the political system by criminal groups has been an enduring problem), in Guatemala measures for accountability and transparency will be crucial. With transparency and accountability in municipal government operations and electoral processes, competition among parties vying for municipal control would empower the community via the ballot box.

As is clear from other Latin American cases, to be effective decentralization will require autonomous and active local judiciaries and attorneys general, free press, and electoral councils, which at present few Guatemalan municipalities could claim. For this reason it is not a reform that should be undertaken all at once, but piece by piece over time as local institutions grow stronger, and through different steps and with different resources depending on specific community strengths and deficiencies. A positive first step could be the establishment of a clear system of municipal and departmental evaluation, to

\footnotetext{
${ }^{53}$ This reform does not need to affect existing redistributive measures from federal revenues which aid under-developed municipalities.
} 
determine the processes necessary for each local government to become capable of collecting and managing new resources effectively. 



\section{References}

\section{Statistics}

Ministerio de Educación de Guatemala. "Anuario Estadístico de la Educación1994-2007”. http://www.mineduc.gob.gt/estadistica/2007/anuario/main.html

\section{Research papers}

Adams, T.M. (2011, February). "How Does Chronic Violence Affect Social Relations and Citizenship? A Survey of New Social Norms in Latin America" (draft paper shared by the author, not for distribution).

Arias, Enrique Desmond. "The Dynamics of Criminal Governance: Networks and Social Order in Rio de Janeiro,” Journal of Latin American Studies, 38, 2006, 293-325.

Brands, Hal, Crime, Violence, and the Crisis In Guatemala: A case study in the erosion of a state. U.S. Army War College Strategic Studies Institute, May 2010.

Krishna A., "How Does Social Capital Grow? A Seven-Year Study of Villages in India". The Journal of Politics, Vol. 69, No. 4, November 2007,pp. 941-956.

Putnam, R. "Bowling Alone: America's Declining Social Capital”. Journal of Democracy 6:1, January 1995, 65-78.

\section{Studies}

Anonymous. "Grupos de poder en Petén: Territorio, política y negocios". Available at: www.libertopolis.com/?dl_id=11.July 2011.

Briscoe, I., "Conflictos en la frontera: Las nuevas zonas calientes en América Latina”. FRIDE, July 2008. 
Dardón, J., "La franja fronterizas de Guatemala con México: Características, sitios de cruce, flujos migratorios y gobernabilidad". Paper presented at the "I Encuentro Internacional sobre Desarrollo e Integración Regional en el Sur de México”. FLACSO Guatemala, June 4 -6 2006.

DeShazo, Peter, Johanna Mendelson Forman, and Phillip McLean. "Countering Threats to Security and Stability in a Failing State: Lessons from Colombia," A Report of the CSIS Americas Program, The CSIS Press, September 2009.

International Crisis Group, "Guatemala: Squeezed between crime and impunity." Latin America Report No 33, June 2010.

Meléndez, J., Orozco, R., Moya, S., López, M., "Una aproximación a la problemática de la criminalidad organizada en las comunidades del Caribe y de Fronteras”. IEEPP, September 2010, p. 13.

Nelson B. J. et al.,"The Concord Handbook: How to Build Social Capital Across

Communities”. UCLA School of Public Policy and Social Research, Los Angeles, California, 2003. http:/ / concord.sppsr.ucla.edu/

United Nations Office on Drugs and Crime. World Drug Report. 2010.

\section{News reports}

Anonymous. "Blake promete mayor control del flujo de personas en la frontera sur". CNN México, May 19, 2011. http://mexico.cnn.com/nacional/2011/05/19/blakepromete-mayor-control-del-flujo-de-personas-en-la-frontera-sur

Brodzinsky, S., "Latin America's middle class grows, but with a tenuous grasp on status". The Christian Science Monitor, May 2011.

http:/ / www.csmonitor.com/World/Americas/2011/0520/Latin-America-s-middle-classgrows-but-with-a-tenuous-grasp-on-status

Gutiérrez E. “El 'boom' del interior”. El Periódico, August 24, 2011.

http://www.elperiodico.com.gt/es/20110113/opinion/188439

Isaacson, Adam. "Rio de Janeiro's Pacification Program” Washington Office on Latin America, January 5, 2011. http://www.wola.org/rio_de_janeiro_s_pacification_program).

Miroff, N. \& Booth, W. "In southern Mexico, a neglected frontier". The Washington Post, June 21, 2011. http:/ /www.washingtonpost.com/world/americas/in-southern-mexico-aneglected-frontier/2011/06/20/AGt74KeH_story.html?wpisrc=emailtoafriend 
Noticias, "Investigan nexos de Chamalé con autoridades de San Marcos". April 4, 2011, http:/ / noticias.com.gt/nacionales/20110404-investigan-nexos-de-chamale-conautoridades-de-san-marcos.html

Ordoñez, M., "El narcotráfico y la deforestación amenazan la biodiversidad”. May 3, 2011.InfoSurHoy.

http://www.infosurhoy.com/cocoon/saii/xhtml/es/features/saii/features/society/2011 /05/03/feature-01

Prensalibre, "Narcos obligan a finqueros a venderles sus propiedades". December 12, 2007, http:/ / www.prensalibre.com/noticias/Narcos-obligan-finqueros-venderlespropiedades_0_169783972.html

Prensalibre, "Expendedores denuncian aumento de ventas ilícitas de combustible." May 2005, http://www.prensalibre.com/noticias/Expendedores-denuncian-aumento-ilicitascombustible_0_479352103.html and "Denuncian incremento de ventas de combustible de contrabando" 


IPR 15225 